\title{
Pharmacological and signalling properties of a D2-like dopamine receptor (Dop3) in Tribolium castaneum
}

\author{
Heleen Verlinden ${ }^{\text {a, b, }{ }^{*}, 1}$, Rut Vleugels ${ }^{\mathrm{a}, 1}$, Rik Verdonck ${ }^{\mathrm{a}}$, Elodie Urlacher ${ }^{\mathrm{b}}$, \\ Jozef Vanden Broeck ${ }^{a}$, Alison Mercer ${ }^{b}$ \\ a Department of Animal Physiology and Neurobiology, Zoological Institute, KU Leuven, Naamsestraat 59, 3000 Leuven, Belgium \\ b Department of Zoology, University of Otago, 340 Great King Street, Dunedin, New Zealand
}

\section{A R T I C L E I N F O}

\section{Article history:}

Received 13 February 2014

Received in revised form

5 November 2014

Accepted 6 November 2014

Available online 15 November 2014

\section{Keywords:}

Amine

Dopamine

Evolution

G protein-coupled receptor (GPCR)

Insect

Pharmacology

Signalling

\begin{abstract}
A B S T R A C T
Dopamine is an important neurotransmitter in the central nervous system of vertebrates and invertebrates. Despite their evolutionary distance, striking parallels exist between deuterostomian and protostomian dopaminergic systems. In both, signalling is achieved via a complement of functionally distinct dopamine receptors. In this study, we investigated the sequence, pharmacology and tissue distribution of a D2-like dopamine receptor from the red flour beetle Tribolium castaneum (TricaDop3) and compared it with related $G$ protein-coupled receptors in other invertebrate species.

The TricaDop3 receptor-encoding cDNA shows considerable sequence similarity with members of the Dop3 receptor class. Real time qRT-PCR showed high expression in both the central brain and the optic lobes, consistent with the role of dopamine as neurotransmitter. Activation of TricaDop3 expressed in mammalian cells increased intracellular $\mathrm{Ca}^{2+}$ signalling and decreased NKH-477 (a forskolin analogue)stimulated cyclic AMP levels in a dose-dependent manner. We studied the pharmacological profile of the TricaDop3 receptor and demonstrated that the synthetic vertebrate dopamine receptor agonists, 2 amino- 6,7 - dihydroxy - 1,2,3,4 - tetrahydronaphthalene hydrobromide (6,7-ADTN) and bromocriptine acted as agonists. Methysergide was the most potent of the antagonists tested and showed competitive inhibition in the presence of dopamine. This study offers important information on the Dop3 receptor from Tribolium castaneum that will facilitate functional analyses of dopamine receptors in insects and other invertebrates.
\end{abstract}

๑) 2014 Elsevier Ltd. All rights reserved.

\section{Introduction}

The biogenic amine dopamine (DA) is an important neurotransmitter both in vertebrates and in invertebrates. DA is implicated in many functions including locomotion, cognition and development. Furthermore, abnormalities in DA signalling are believed to play a role in a number of human disorders, such as schizophrenia, Parkinson's disease, Tourette's syndrome, bipolar disorder, Huntington's disease, attention deficit hyperactivity disorder (ADHD) and drug addiction (Andre et al., 2010; Ares-Santos et al., 2013; Buse et al., 2013; Cousins et al., 2009; Emsley et al.,

\footnotetext{
* Corresponding author. Zoological Institute, Naamsestraat 59 box 2465, 3000 Leuven, Belgium. Tel.: +32 16 324260; fax: +32 16323902 .

E-mail address: heleen.verlinden@bio.kuleuven.be (H. Verlinden).

1 These authors contributed equally to this work.
}

2013; Gazewood et al., 2013; Wu et al., 2012). In vertebrates, five distinct $G$ protein-coupled DA receptors mediate all known functions of DA. They can be divided in two major groups based on their structural, pharmacological and biochemical properties: D1-class DA receptors (D1 and D5, which may also be referred to as D1A and D1B since they are presumably closely related paralogues that arose from a gene duplication event) and D2-class DA receptors (D2, D3 and D4) (Beaulieu \& Gainetdinov, 2011; Callier et al., 2003; Cardinaud et al., 1998).

Because DA is critically involved in a number of physiological processes, the mode of action, in vivo function and regulation of vertebrate DA receptors have been extensively studied (Strange, 2005). However, much less is known about invertebrate DA receptors. Because of the conservation of common functional properties, the three types of DA receptors typically found in invertebrates are generally categorised according to the classification system used for vertebrate DA receptors. Members of the 
Dop1 group of invertebrate DA receptors, which includes DromeDop1/dDA1 and ApimeDop1, are closely related to the vertebrate D1 class of receptors. Members of the Dop2/INDR (invertebrate specific dopamine receptors) group, which includes DAMB/DopR99B and ApimeDop2, also show more sequence similarity with D1-like receptors than with D2-like receptors. However, the Dop3 class, which includes DromeDD2 and ApimeDop3, are more closely related to the vertebrate D2 class of dopamine receptors (Barbas et al., 2006; Beggs et al., 2011; McDonald et al., 2006; Meyer et al., 2011; Missale et al., 1998; Mitsumasu et al., 2008; Mustard et al., 2005). Dop1 and Dop2 are functionally D1-like and activate adenylyl cyclase (Blenau et al., 1998; Humphries et al., 2003; Mustard et al., 2003). In contrast, Dop3 are functionally D2-like in that they inhibit adenylyl cyclase (Beggs and Mercer, 2009; Beggs et al., 2005; Hearn et al., 2002). An additional receptor that interacts with both DA and ecdysone has been characterised in Drosophila melanogaster. However, this receptor is not closely related to the other dopamine receptors and will not be further discussed (Evans et al., 2014; Srivastava et al., 2005).

Nevertheless, multiple indications exist that this traditional view of DA receptor signalling is much too simple (as also discussed in Beggs et al., 2005; Clark and Baro, 2007). More and more proof is provided concerning the signalling complexity of GPCRs in general and of DA receptors specifically. GPCRs, including DA receptors, can switch $G$ protein coupling over time in response to constant agonist application, both the $G_{\alpha}$ and $G_{\beta \gamma}$ subunits are known to elicit individual responses and $G$ proteins can directly act with target proteins. Moreover also $G$ protein independent cascades, for example $\beta$-arrestin, influence the cellular response (the reader is referred to Clark and Baro, 2007; Verlinden et al., 2014 and references herein).

In 2011, Beggs and co-workers compared the pharmacological properties of some Apis mellifera dopamine and octopamine/ tyramine receptors (Beggs et al., 2011). Their data were supported by phylogenetic analyses (Balfanz et al., 2005; Hauser et al., 2006, 2008; Humphries et al., 2003; Mustard et al., 2003, 2005) indicating that some of the DA and octopamine receptor genes are paralogues. The most recent classification has grouped insect/ invertebrate octopamine receptors into three classes: $\alpha$-adrenergic-like octopamine receptors (Oct $\alpha \mathrm{R}$ ), $\beta$-adrenergic-like octopamine receptors (Oct $\beta R$ ) and octopamine/tyramine or tyramine receptors (TyrRI and TyrRII) (Bayliss et al., 2013; Evans and Maqueira, 2005; Verlinden et al., 2010). Dop1 receptors share pharmacological similarities with $\operatorname{Oct} \beta R$ and like Oct $\beta R$, activation of Dop1 receptors causes an increase in intracellular cAMP levels (Blenau et al., 1998; Gotzes et al., 1994; Mitsumasu et al., 2008; Mustard et al., 2003; Sanyal et al., 2004; Sugamori et al., 1995). Dop2 receptors are pharmacologically most similar to Oct $\alpha \mathrm{R}$ and like Oct $\alpha \mathrm{R}$, activation of Dop2 receptors causes an increase in both intracellular cAMP and intracellular calcium levels (Beggs et al., 2011; Feng et al., 1996; Gerber et al., 2006; Han et al., 1996; Humphries et al., 2003; Mitsumasu et al., 2008; Mustard et al., 2003; Troppmann et al., 2014). Dop3 receptors on the other hand, are functionally similar to TyrRI. Like TyrRI, activation of Dop3 receptors has been shown to reduce intracellular cAMP levels (Beggs et al., 2005; Hearn et al., 2002; Suo et al., 2003).

In this study, we analyse the properties of a Dop3 receptor (TricaDop3) from the red flour beetle Tribolium castaneum and demonstrate that this receptor displays dual coupling characteristics. Like TyrRI (Robb et al., 1994; Reale et al., 1997b; Poels et al., 2001), TricaDop3 can elicit a rise in intracellular calcium ion levels, in addition to causing a decrease in intracellular levels of cAMP.

\section{Experimental procedures}

\subsection{Animal rearing conditions and dissections}

Beetles were reared in a dark incubator at $30{ }^{\circ} \mathrm{C}$ on wheat flour and brewer's yeast in Petri dishes of $140 \mathrm{~mm}$ diameter. Adult beetles were sexed based on the presence of a small patch of short bristles on the inside of the first pair of legs in males, according to the Tribolium castaneum rearing protocol (http://bru.gmprc.ksu. edu/proj/tribolium/wrangle.asp) (Beeman et al., 2009).

The different body parts/tissues (head, gut, fat body, gonads, accessory glands, brain, optical lobes, salivary glands) were collected during dissections performed on agar plates $(40 \mathrm{~g} / \mathrm{l})$ in Phosphate Buffered Saline (PBS) ( $\mathrm{NaCl} 137 \mathrm{mM}, \mathrm{KCl} 2.7 \mathrm{mM}$, $\mathrm{Na}_{2} \mathrm{HPO}_{4} 10 \mathrm{mM}, \mathrm{KH}_{2} \mathrm{PO}_{4} 1.76 \mathrm{mM}$; $\mathrm{pH}$ 7.2) under a binocular microscope and snap frozen in liquid nitrogen.

\section{2. mRNA isolation and $c D N A$ synthesis}

For all samples, tissues of at least fifteen animals were pooled. Tissues were homogenised and RNA was extracted using the RNAqueous Micro Kit (Ambion) according to the protocol recommended by the manufacturer. The protocol included an additional DNase treatment to digest remaining DNA. Concentrations and RNA purity were determined with a NanoDrop ND1000 spectrophotometer (NanoDrop Technologies). Total RNA (150 ng) was reverse transcribed into cDNA using SuperScriptIII reverse transcriptase (Invitrogen) as recommended by the manufacturer, and diluted ten-fold prior to use.

\subsection{Cloning of TricaDop3 and construction of pcTricaDop3 expression vector}

The full length sequence encoding the receptor was amplified with PCR using $2 \mu \mathrm{l}$ whole body $T$. castaneum cDNA (see $\S 2.2$ ), Taq polymerase (REDTaq ${ }^{\mathbb{R}}$ ReadyMix ${ }^{\mathrm{TM} P C R}$ Reaction Mix, Sigma-Aldrich), and $10 \mu \mathrm{M}$ of sense primer $5^{\prime}$-CACCATGATCCCTGAAAAAATGGACGC- $3^{\prime}$ and antisense primer 5'-TTAAGGCCCGAGGAACATTAA-3' (Sigma-Aldrich). Primers were designed based on sequences available in Beetlebase (Tcas_3.0; http://www.beetlebase. org/) (Kim et al., 2010) released by the Human Genome Sequencing Center (GenBank Accession Number EFA02832). PCR started with initial denaturation for $2 \mathrm{~min}$ at $95^{\circ} \mathrm{C}$, followed by 35 cycles of $30 \mathrm{~s}$ at $94^{\circ} \mathrm{C}, 30 \mathrm{~s}$ at $62^{\circ} \mathrm{C}$ and $2 \mathrm{~min}$ at $72^{\circ} \mathrm{C}$, followed by final elongation for $5 \mathrm{~min}$ at $72{ }^{\circ} \mathrm{C}$. Amplification products were run on a $1 \%$ agarose gel and purified with the GenElute ${ }^{\mathrm{TM}}$ Gel extraction Kit (Sigma-Aldrich). The DNA fragment was cloned into a pcDNA3.1D/V5-His-TOPO ${ }^{\circledR}$ expression vector via TOPO cloning (Invitrogen) and transformed into One Shot TOP10 chemically competent Escherichia coli cells (Invitrogen). Bacteria were grown according to the protocol recommended by the kit. Plasmids were isolated via the GenElute ${ }^{\mathrm{TM}} \mathrm{HP}$ Plasmid Miniprep kit (Sigma-Aldrich) and DNA sequences were determined by means of the ABI PRISM 3130 Genetic Analyser (Applied Biosystems) following the protocol outlined in the ABI PRISM BigDye Terminator Ready Reaction Cycle Sequencing Kit (Applied Biosystems). Bacterial cells known to contain the correct receptor insert were grown at large scale in $100 \mathrm{ml}$ Luria-Bertani broth medium. The expression vectors were subsequently isolated from these cells using the EndoFree Plasmid Maxi Kit (Qiagen) according to the protocol recommended by the manufacturer.

\subsection{Multiple sequence alignment}

Amino acid sequences of the Dop3 of the fruit fly and honey bee, used for the sequence alignment, were identified in the protein 
database of NCBI. The multiple sequence alignment was performed with MAFFT (L-INS-i method) (Katoh et al., 2002, 2005).

\section{5. qRT-PCR study of transcript levels}

The cDNA synthesised in $\S 2.2$ was used as template to determine the relative transcript levels of the TricaDop3 receptor. They were quantified using the Fast Sybr Green assay kit (Applied Biosystems) in a StepOne Plus detection system (ABI Prism, Applied Biosystems). Primers (sense primer 5'-TCGGCAACGTGCTTGTGAT-3' and antisense primer 5'-TTAGTGGCCGACTGCAGAGTT-3') (Sigma-Aldrich) were used in final concentrations of $500 \mathrm{nM}$. Reactions were run in duplicate and incubated at $50^{\circ} \mathrm{C}$ for $2 \mathrm{~min}$, followed by $95^{\circ} \mathrm{C}$ for $10 \mathrm{~min}$, followed by 40 cycles of $\left[95^{\circ} \mathrm{C}\right.$ for $15 \mathrm{~s}$ and $60^{\circ} \mathrm{C}$ for $1 \mathrm{~min}]$. The specificity of the PCR products was assessed by generating a dissociation curve $\left(95^{\circ} \mathrm{C}\right.$ for $15 \mathrm{~s}, 60^{\circ} \mathrm{C}$ for $1 \mathrm{~min}$, and increases in temperature in $0.7^{\circ} \mathrm{C}$ increments from $60{ }^{\circ} \mathrm{C}$ to $95^{\circ} \mathrm{C}$ ). Analysis of the dissociation curves of the different amplification products revealed a single melting peak. We detected no amplification of the fluorescent signal in the negative control samples (no template control, $\mathrm{RT}^{-}=\mathrm{RNA}$ sample as template), proving that the extraction procedure, including the DNase treatment, effectively removed genomic DNA from all the RNA samples and that there was no contamination. Agarose gel electrophoresis of the PCR products confirmed the presence of a single band of the expected size and sequencing confirmed their identity. The relative quantity of target cDNA was quantified using the $\Delta \Delta \mathrm{C}_{\mathrm{T}}$-method including normalisation to the geometric mean (a type of mean or average, which indicates the central tendency or typical value of a set of numbers by using the product of their values as opposed to their sum) of a selection of endogenous control genes. From a list of eight housekeeping genes (Supplementary table), both ribosomal proteins RPs3 and RPs18, and actin were selected using geNorm (Vandesompele et al., 2002) as stable genes with respect to sex and tissue and used as endogenous controls (Vuerinckx et al., 2011).

\subsection{Cell culture and transfections}

Preliminary pharmacological analyses were performed in Chinese hamster ovary ( $\mathrm{CHO}$ ) WTA11 cells stably co-expressing the bioluminescent protein apoaequorin (Brough and Shah, 2009) and the promiscuous $G_{\alpha 16}$ subunit, which couples most agonistinduced GPCRs to the phospholipase $\mathrm{C}$ and $\mathrm{Ca}^{2+}$ pathway, irrespective of their natural signalling cascade (Milligan et al., 1996; Offermans and Simon, 1995; cells were obtained from the Free University of Brussels and Euroscreen, Belgium). In subsequent experiments, CHO-PAM28 cells stably expressing apoaequorin, but not the promiscuous $\mathrm{G}_{\alpha 16}$ (Free University of Brussels and Euroscreen, Belgium), and human embryonic kidney (HEK) 293 cells (Invitrogen) were used to measure TricaDop3's downstream signalling properties via $\mathrm{Ca}^{2+}$ and cAMP, respectively (Dillen et al., 2013).

CHO-WTA11 cells, CHO-PAM28 cells and HEK 293 cells were cultured in monolayers in Dulbecco's Modified Eagles Medium nutrient mixture F12-Ham (DMEM/F12) (Sigma-Aldrich) supplemented with $100 \mathrm{IU} / \mathrm{ml}$ penicillin and $100 \mu \mathrm{g} / \mathrm{ml}$ streptomycin (Gibco) to prevent bacterial contamination of gram-positive and gram-negative bacteria, respectively. For $\mathrm{CHO}$ cells the medium was also supplemented with $10 \%$ heat-inactivated fetal bovine serum (Gibco). The medium used for HEK 293 cells was supplemented with Ultroser $\mathrm{G}$ (Crescent Chemical Company). For CHOWTA11 cells, $250 \mathrm{mg} / \mathrm{ml}$ zeocin (Gibco) was added to the medium, whereas for CHO-PAM28 cells, $5 \mu \mathrm{g} / \mathrm{ml}$ puromycin (Sigma-Aldrich) was added to the medium. Puromycin and zeocin were initially used to select for cells stably expressing apoaequorin (CHO-
PAM28) (Torfs et al., 2002), or both apoaequorin and G $\alpha 16$ (CHOWTA11 cells) (Blanpain et al., 1999) and are thus still used as additional antibiotics in the appropriate screens. All cells were maintained in an incubator at $37{ }^{\circ} \mathrm{C}$ with a constant supply of $5 \%$ $\mathrm{CO}_{2}$.

Transfections with pcDNA3.1-TricaDop3 or empty pcDNA3.1 vector were carried out in T75 flasks at 60-80 \% confluency. Transfection medium for $\mathrm{CHO}$ cells was prepared using the Lipofectamine LTX Kit (Invitrogen) with 2.5 ml Opti-MEM ${ }^{\circledR}$ (Gibco), $12.5 \mu \mathrm{l}$ Plus $^{\mathrm{TM}}$ Reagent and $5 \mu \mathrm{g}$ vector construct (pcDNA3.1-TricaDop3 or empty pcDNA3.1 vector) in $5 \mathrm{ml}$ polystyrene round-bottom tubes. After a $5 \mathrm{~min}$ incubation period at room temperature, $30 \mu \mathrm{l}$ LTX was added to the medium. After a further incubation period of $30 \mathrm{~min}$ at room temperature, the medium was removed and DNA/ LTX mix was added dropwise to the cells followed by $3 \mathrm{ml}$ of fresh complete medium. The transfection medium used for HEK293 cells was similar to that used for $\mathrm{CHO}$ cells except that in addition to $4 \mu \mathrm{g}$ of pcDNA3.1-TricaDop3 expression construct (or empty pcDNA3.1 vector plasmid) cells were co-transfected with $2 \mu \mathrm{g}$ of reporter $\mathrm{CRE}_{(6 \mathrm{x})}$-Luc plasmid. This reporter plasmid contains six tandem repeats of a cAMP Responsive Element (CRE) in front of a minimum collate promoter and the ORF of luciferase (this reporter plasmid was also used in various other studies: for example Hearn et al., 2002; Johnson et al., 2004). To test whether the concentration of receptor used for the transfection affects the cAMP concentration the same transfection was also carried out with 1 and $8 \mu \mathrm{g}$ of pcDNA3.1 receptor expression construct.

Following transfection, cells were incubated overnight $\left(37^{\circ} \mathrm{C}\right.$, $5 \% \mathrm{CO}_{2}$ ), then $10 \mathrm{ml}$ of cell medium was added followed by a second overnight incubation $\left(37{ }^{\circ} \mathrm{C}, 5 \% \mathrm{CO}_{2}\right)$. Ligand-induced changes in either, intracellular $\mathrm{Ca}^{2+}$ or cAMP were then monitored in the cells as described below.

\subsection{Calcium reporter assay in $\mathrm{CHO}$ cells}

CHO cells transfected with vector construct (pcDNA3.1-TricaDop3 or empty pcDNA3.1 vector) were detached with PBS, complemented with $0.2 \%$ EDTA ( $\mathrm{pH} 8.0$ ), and rinsed off the flask with complete DMEM/F12. The number of viable and nonviable cells was determined using a NucleoCounter ${ }^{\mathbb{B}}$ NC-100 ${ }^{\mathrm{TM}}$ (Chemometic). The cells were pelleted for $5 \mathrm{~min}$ at $800 \mathrm{rpm}$ and resuspended to a density of $5 \times 10^{6}$ cells $/ \mathrm{ml}$ in sterile filtered bovine serum albumin (BSA) medium (DMEM/F12 with L-glutamine and $15 \mathrm{mM}$ Hepes, without phenolred, supplemented with $0.1 \%$ BSA) and loaded with $5 \mu \mathrm{M}$ Coelenterazine_h (Invitrogen) for $4 \mathrm{~h}$ in the dark, at room temperature, while gently shaking to reconstitute the holo-enzyme aequorin. After a tenfold dilution, cell solution $(50 \mu \mathrm{l})$ was delivered to each well in a 96-well plate $(\sim 25000$ cells/well) and cells were exposed to potential ligands reconstituted in BSA medium and distributed across the plate. In every row, BSA medium without potential ligands was placed in one well to serve as the blank for that row. The calcium response was recorded for $30 \mathrm{~s}$ on a multimode microplate reader Mithras LB 940 at a wavelength of $469 \mathrm{~nm}$ (Berthold Technologies). After $30 \mathrm{~s}, 0.1 \%$ Triton X-100, a non-ionic surfactant, was added to the same well to measure the total cellular $\mathrm{Ca}^{2+}$ response. The total response (ligand + Triton X-100), which is directly related to the number of cells present in the well, was used to normalise the response for possible different amounts of cells per well. The response of each blank (small signal caused by cells ruptured by the injection in the wells) was subtracted from the luminescence obtained for wells within the same row. Calculations were made using the output file from the Microwin software (Berthold Technologies) in Excel (Microsoft). Further analysis was done in Excel and GraphPad Prism 5. 


\subsection{Cyclic AMP (cAMP) reporter assay in HEK cells}

To monitor changes in intracellular cAMP levels, HEK293 cells co-transfected with receptor construct (pcDNA3.1-TricaDop3 or empty pcDNA3.1 vector) and reporter $\mathrm{CRE}_{(6 \mathrm{x})}$-Luc plasmid were detached with PBS, complemented with $0.2 \%$ EDTA ( $\mathrm{pH} \mathrm{8.0),} \mathrm{and}$ rinsed off the flask with complete DMEM/F12. The number of viable and nonviable cells was determined using the NucleoCounter ${ }^{\circledR}$ NC$100^{\mathrm{TM}}$. The cells were pelleted for $5 \mathrm{~min}$ at $800 \mathrm{rpm}$ and finally resuspended to a density of $1 \times 10^{6}$ cells/ml in DMEM/F12 without phenolred (Invitrogen), but containing $200 \mu \mathrm{M}$ 3-isobutyl-1methylxanthine (IBMX, Sigma-Aldrich) to prevent cAMP breakdown. Into each well of a white 96 -well plate $50 \mu$ l of cell suspension $(\sim 50000$ cells/well) was added to either $50 \mu \mathrm{l}$ of phenol red-free DMEM/F-12 with IBMX (to prevent breakdown of cAMP) or phenol red-free DMEM/F-12 with IBMX containing $10 \mu \mathrm{M}$ NKH477 (a forskolin analogue), which was used to enhance cAMP levels in the cells. In each row of the plate at least one well with only phenol red-free DMEM/F-12 with IBMX was measured. This well is used to calculate the 'blank' level (Fig. 8). The cells were then incubated $\left(37^{\circ} \mathrm{C}, 5 \% \mathrm{CO}_{2}\right)$ for $3-4 \mathrm{~h}$. Thereafter, $100 \mu \mathrm{l}$ of steadylite plus $^{\mathrm{TM}}$ substrate (PerkinElmer) was added to each well using a multichannel pipette and the plate was incubated for $15 \mathrm{~min}$ in the dark. Finally, light emission resulting from the luciferase enzymatic activity was recorded for $0.2 \mathrm{~s} /$ well every $55 \mathrm{~s}$ during 10 cycles on a multimode microplate reader FLUOstar Omega at a wavelength of $469 \mathrm{~nm}$ (BMG Labtech). Results were analysed by means of the Omega software and further processed by Excel and GraphPad Prism5 software.

\subsection{Drugs}

The pharmacological ligands ( \pm )-2-amino-6,7 - dihydroxy 1,2,3,4 - tetrahydronaphthalene hydrobromide (6,7-ADTN), 3hydroxytyramine (dopamine, DA), bromocriptine mesilate, 5methoxytryptamine (5-MT), (+)-butaclamol hydrochloride, chlorpromazine hydrochloride, cis-(Z)-flupenthixol, DL-octopamine hydrochloride, ketanserin (+)-tartrate, methiothepin mesylate, methysergide maleate, mianserin hydrochloride, prazosin hydrochloride, SB-269970 hydrochloride, tyramine hydrochloride, WAY100635 maleate (WAY = N-(2-[4-(2-methoxyphenyl)-1piperazinyl]-ethyl)-N-(2-pyridinyl) cyclohexanecarboxamide), spiperone ( $\mathrm{N}$-(p-Isothiocyanatophenethyl)spiperone hydrochloride), NKH-477 and yohimbine hydrochloride were purchased from Sigma-Aldrich.

\section{Results}

\subsection{Cloning and sequence analysis of TricaDop3}

The PCR amplified a single cDNA fragment encoding a Dop3 from $T$. castaneum. The open reading frame of Tricadop3 contains 1641 nucleotides encoding the TricaDop3 protein of 546 amino acids (Fig. 1) with a calculated molecular weight of $60.16 \mathrm{kDa}$. Transmembrane topology prediction revealed the presence of seven putative transmembrane domains (TM1-7), characteristic of all GPCRs. The large third intracellular loop and the short intracellular C-terminal region are typical features of biogenic amine receptors that couple via $G_{i}$ (Gerhardt et al., 1996; Kroeze et al., 2002) and are also found in mammalian D2-like DA receptors (Missale et al., 1998). At the N-terminus of the second intracellular loop is the highly conserved DRY sequence $\left(D^{3.49} R^{3.50} Y^{3.51}\right)$ [numbering according to the Ballesteros-Weinstein system (Ballesteros and Weinstein, 1995), believed to have a key role in receptor activation (Bockaert and Pin, 1999; Gether, 2000)]. More specific sequence characteristics for biogenic amine receptors are present as well. Two aspartate residues in TM2 and TM3 ( $\mathrm{D}^{2.50}$ and $\mathrm{D}^{3.32}$ ) that are conserved in all catecholamine receptors are thought to play a role in binding the protonated amine moiety of catecholamines (Chung et al., 1988; Fraser et al., 1988; Ho et al., 1992; Strader et al., 1987, 1988). The combination of this $D^{3.32}$ in TM3 with the conserved $\mathrm{W}^{7.40}$ in TM7 is considered a unique fingerprint for biogenic amine and trace amine GPCRs (Huang, 2003; Spitzer et al., 2007). As in other biogenic amine receptors, TricaDop3 has a hydrophobic ligand binding pocket consisting of mainly aromatic amino acids residues from TM4-TM7 $\left(\mathrm{W}^{4.50}\right.$ in TM4, $\mathrm{F}^{5.47}$ in TM5, $W^{6.48}, F^{6.51}, F^{6.52}$ in TM6, and $W^{7.40}, Y^{7.43}$ in TM7) (Roth et al., 1997). Moreover, as for all catecholamine receptors, three conserved serine residues in TM5 are postulated to be hydrogen bond donors to bind the catecholamine ring hydroxyl groups $\left(S^{5.42}, S^{5.43}\right.$, and $S^{5.46}$ ) (Pollock et al., 1992; Strader et al., 1989). The alignment shows a fourth conserved serine residue in the insect Dop3 receptors, possibly involved in hydrogen bonding to DA. In addition, a disulphide bond between $\mathrm{C}^{3.25}$ and $\mathrm{C}^{5.31}$ in extracellular loop 1 and 2 respectively, is believed to stabilise the functional receptor structure (Dixon et al., 1987; Fraser, 1989; Karnik and Khorana, 1990; Karnik et al., 1988; Noda et al., 1994).

In TM6, the consensus sequence of non-peptide receptors $\left(\mathrm{F}^{6.44} \mathrm{XxxW}^{6.48} \mathrm{P}^{6.50}\right)$ is followed by a pair of Phe residues $\left(\mathrm{F}^{6.51}\right.$ and $\mathrm{F}^{6.52}$ ) unique to aminergic receptors. In TM7, the $\mathrm{N}^{7.49} \mathrm{P}^{7.50} \mathrm{xxY}^{7.53}$ motif is conserved. Mutagenesis experiments along this domain have been shown to affect the receptor's ligand affinity, G protein coupling, receptor signalling, desensitisation and internalisation (Barak et al., 1994; Birse et al., 2006; Borroto-Escuela et al., 2011; Fritze et al., 2003; Gales et al., 2000; Gripentrog et al., 2000; Kalatskaya et al., 2004).

As for most GPCRs, consensus motifs for N-linked glycosylation (N-X-[S/T]) (Marshall, 1974; Swarz and Aebi, 2011) are found in the extracellular $\mathrm{N}$-terminus, and consensus sites for phosphorylation by protein kinase C (PKC) ([S/T-X-[R/K]) (Woodgett et al., 1986) are located within the third intracellular loop (Fig. 1).

Comparison of the Dop3 amino acid sequences of $A$. mellifera, $D$. melanogaster and T. castaneum revealed high sequence similarities. Overall sequence similarity of TricaDop3 (identical and conservatively substituted amino acids) compared to insect Dop3 orthologues is $78.0 \%$ for A. mellifera (GenBank Accession Number AAX62923) and $71.3 \%$ for D. melanogaster (GenBank Accession Number Q8IS44.1). Sequence similarity is even higher within the TM regions: $96.9 \%$ for $A$. mellifera and $96.3 \%$ for D. melanogaster.

\subsection{Transcript level study}

An initial tissue distribution screen of TricaDop3 mRNA in sexually mature beetles was performed using qRT-PCR (Fig. 2). Transcript levels of the Tricadop3 gene were relatively high in the head compared to the gut, fat body, gonads and accessory gland. No significant differences could be detected between males and females (Fig. 2A). In an additional experiment in sexually mature males it appears that the transcript levels of the Tricadop3 gene are especially pronounced in the central nervous system, represented by the central brain and optic lobes (Fig. 2B).

\subsection{Pharmacological characterisation of TricaDop3}

In order to begin our pharmacological characterisation of TricaDop3 receptors, we used CHO-WTA11 cells stably expressing aequorin and the promiscuous $G_{\alpha 16}$ subunit. No alteration of the signal was observed when cells transfected with empty pcDNA3.1 vector were incubated with DA (results not shown). A significant response, however, was obtained upon application of micromolar 
$\diamond$

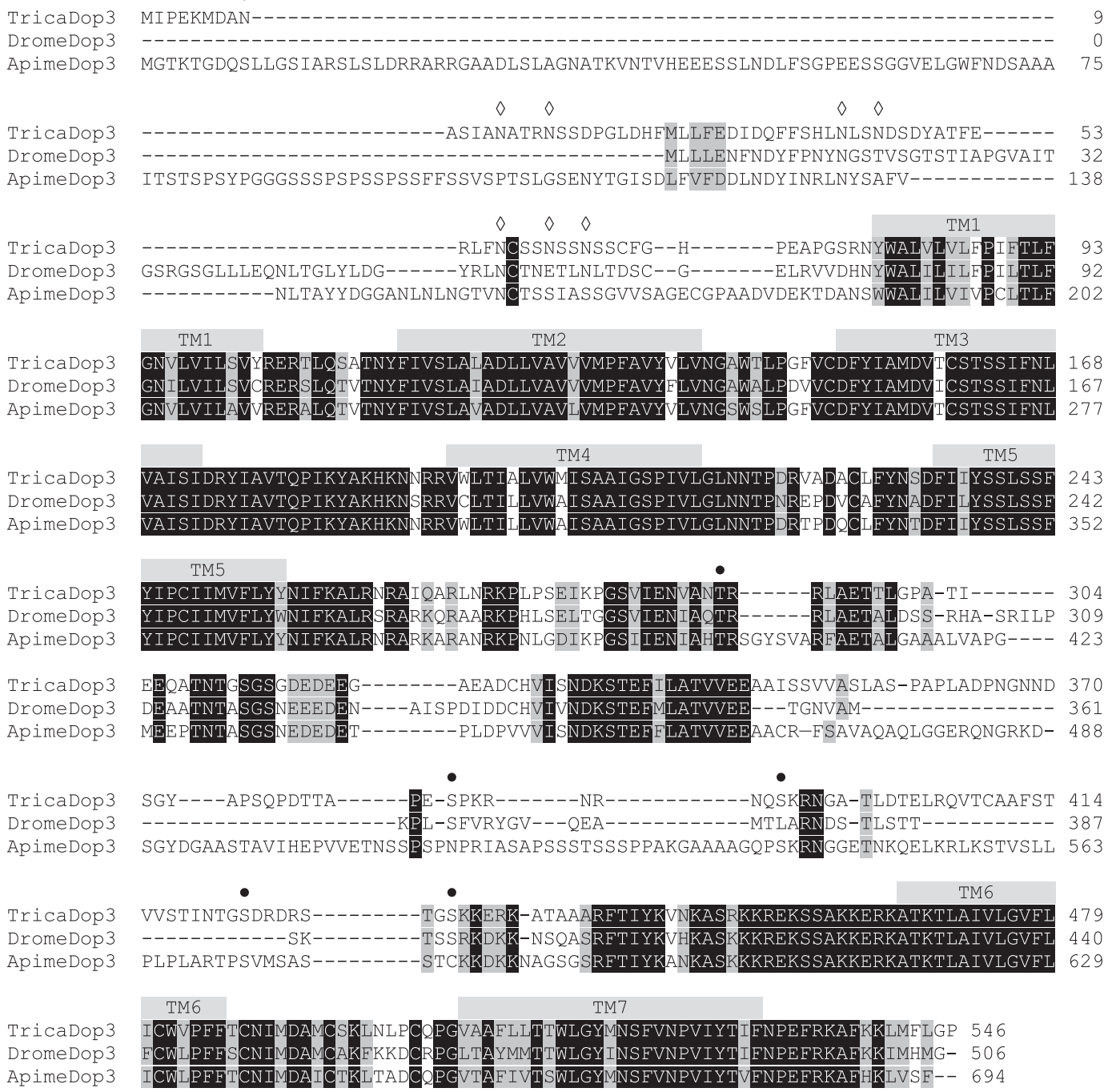

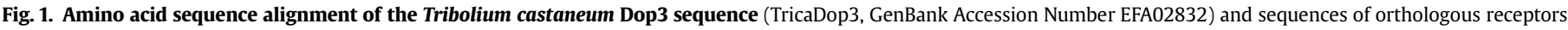

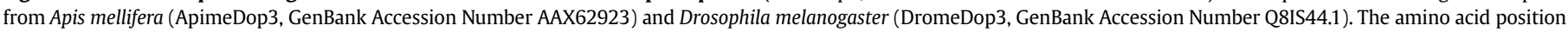

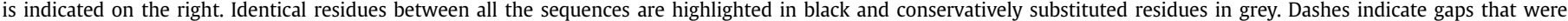

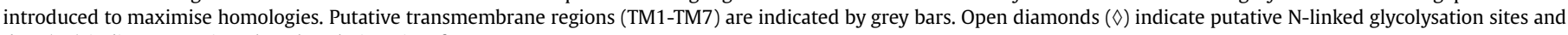
dots (๑) indicate putative phosphorylation sites for PKC.

concentrations of DA to TricaDop3 expressing cells. The effects of micromolar concentrations of potential synthetic agonists were subsequently tested (Fig. 3, Table 1). The biogenic amines octopamine and tyramine induced a clear signal at concentrations of $100 \mu \mathrm{M}$ (but not of $1 \mu \mathrm{M}$ ). The mammalian D2-selective receptor agonist bromocriptine and the mixed D1/D2-like receptor agonist 6,7-ADTN induced signals that were similar in magnitude to those measured for DA. An agonist of 5-HT-receptors, 5-MT, also induced considerable receptor activation. The dose-response relationships for DA, tyramine and the two potent synthetic dopaminergic agonists were examined at concentrations ranging from $0.01 \mathrm{nM}$ to $10 \mathrm{mM}$ (Fig. 4). The resulting sigmoidal dose-response curves show receptor activation in a dose-dependent and saturable manner. For the natural agonist DA, half-maximal activation ( $\left.\mathrm{EC}_{50}\right)$ was achieved at DA concentrations of $640 \mathrm{nM}$ [510-810 nM, 95\% confidence interval $(\mathrm{CI})$ ]. The maximal response was attained at DA concentrations of $\geq 100 \mu \mathrm{M}$. Since the efficacy achieved by any agonist depends on the number of receptors expressed, we measured a dose-response curve for DA in every experiment and normalised all agonist effects to the maximum DA response, set at $100 \%$ (Fig. 4). The $\mathrm{EC}_{50}$ values of the synthetic agonists bromocriptine and 6,7-ADTN were $1.2 \mu \mathrm{M}(0.8-1.7 \mu \mathrm{M}, 95 \% \mathrm{CI})$ and $2.8 \mu \mathrm{M}(2.0-3.8 \mu \mathrm{M}, 95 \% \mathrm{CI})$, respectively. Tyramine had an $\mathrm{EC}_{50}$ value of $60 \mu \mathrm{M}(51-71 \mu \mathrm{M}, 95 \% \mathrm{CI})$, and concentrations in the micromolar range are needed to induce any response (Figs. 3 and 4 ). The rank order of potencies thus is DA $\geq$ bromocriptine $\geq 6,7$ ADTN > tyramine, with only subtle differences between the first three potent agonists (Figs. 3 and 4, Table 1).

Potential antagonists were tested by simultaneously applying DA $(1 \mu \mathrm{M})$ and a high dose of antagonist $(100 \mu \mathrm{M})$ to TricaDop3expressing CHO-WTA11 cells. In TricaDop3-expressing CHOWTA11 cells, the mammalian DA receptor antagonist spiperone and the mammalian 5-HT receptor antagonists ketanserin, methiothepin, prazosin, SB-269970 and WAY-100635 had no effect on DA signalling at the used concentrations. However, butaclamol and chlorpromazine (two mammalian DA receptor antagonists) and yohimbine (an antagonist of vertebrate $\alpha 2$ receptors) inhibited the DA response by about $40 \%$, while the DA receptor antagonist flupenthixol blocked about $60 \%$ of the DA response (Table 1). Interestingly, mianserin and methysergide, generally known as antagonists of mammalian 5-HT receptors, were the most potent blockers of DA signalling with an inhibition of respectively $80 \%$ and 
A

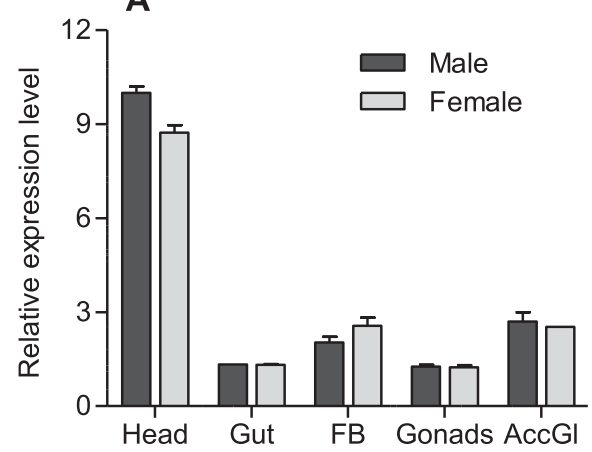

B

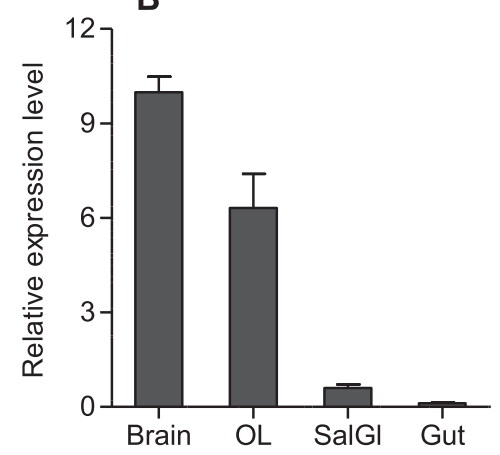

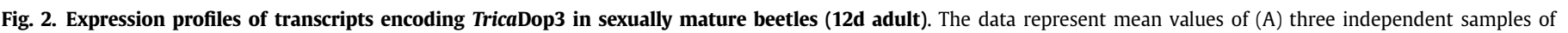

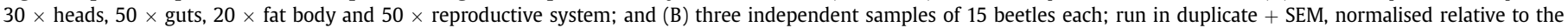

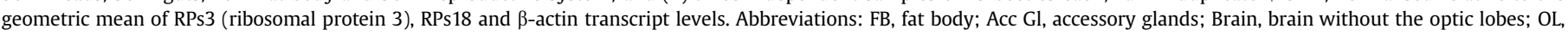
optic lobes; SalGl, salivary glands.

$100 \%$ (in presence of $100 \mu \mathrm{M}$ antagonist and $1 \mu \mathrm{M} \mathrm{DA}$ ). The effects of methysergide and mianserin were tested into more detail in TricaDop3-expressing CHO-WTA11 cells using two different concentrations of DA. Significant inhibition of the DA response was measured using micromolar concentrations of the antagonists, with methysergide being clearly the most potent blocking agent (Fig. 5). The nature of this inhibition was further examined by studying the dose-response relationship of DA in the presence of methysergide at several different concentrations (Fig. 6). The higher the concentration of antagonist, the higher was the resulting $\mathrm{EC}_{50}$ value for DA activity. The corresponding $\mathrm{pA} 2$ value (i.e. the logarithm of the concentration of antagonist that doubles the amount of DA required for obtaining the same effect) was calculated using the Gaddum/Schild plot (Kenakin, 1982). The pA2 value $( \pm$ SEM) was $5.74( \pm 0.15)$. Since the efficacy did not change, it is very likely that methysergide behaved as a truly competitive antagonist on TricaDop3 in presence of DA. A high dose $(100 \mu \mathrm{M})$ of all active chemicals was also tested on cells transfected with empty pcDNA3.1 vector and could not induce a signal in these cells.

\subsection{Downstream signalling properties of TricaDop3}

CHO-PAM28 and HEK293 cells were used to determine the downstream signalling pathway of TricaDop3. Again, no alteration

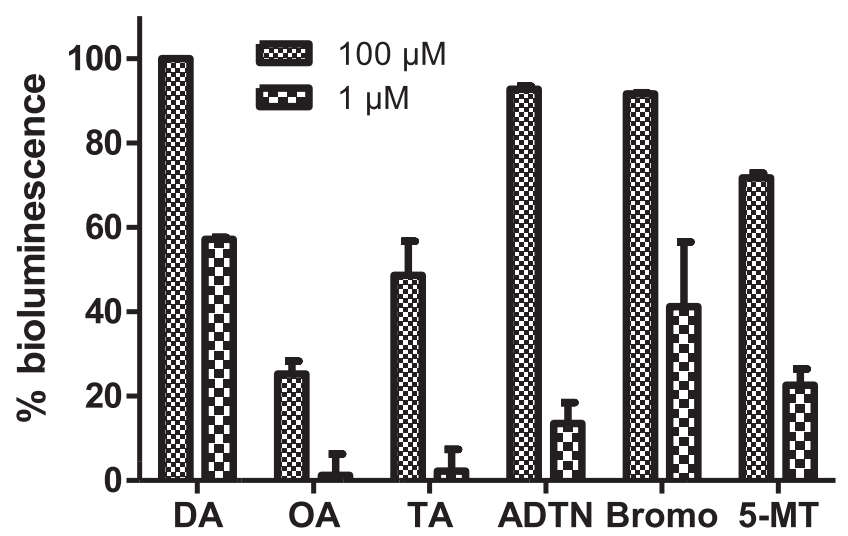

Fig. 3. Activation of TricaDop3 in CHO-WTA11 cells by agonists at two different concentrations. Bioluminescence levels measured in blanks were subtracted and the data are presented relative to responses obtained using $100 \mu \mathrm{M}$ dopamine alone (100\%). The bars represent mean values + SEM. Abbreviations used: DA, dopamine; OA, octopamine; TA, tyramine; ADTN, 6-amino-5,6,7,8-tetrahydronaphthalene-2,3-diol hydrobromide; Bromo, bromocriptine; 5-MT, 5-methoxytryptamine. Measurements were performed in triplicate. of the signal was observed when either of these cell lines, transfected with empty pcDNA3.1 vector, was incubated with DA (results not shown). Calcium signals in response to DA concentrations ranging from $0.01 \mathrm{nM}$ to $1 \mathrm{mM}$ were monitored in TricaDop3expressing CHO-PAM28 cells. Responses to DA application were dose dependent, indicating that even without the presence of the promiscuous $G_{\alpha 16}$, the activation of the TricaDop3 receptor affects intracellular calcium levels (Fig. 7). An $\mathrm{EC}_{50}$ value of $0.6 \mu \mathrm{M}$ $(0.24 \mu \mathrm{M}-1.5 \mu \mathrm{M}, 95 \% \mathrm{CI})$ was measured. Effects of DA on intracellular cAMP levels were examined in TricaDop3-expressing HEK293 cells using DA concentrations ranging from $0.01 \mathrm{nM}$ to $10 \mathrm{mM}$. DA caused a dose-dependent decrease in NKH-477stimulated cAMP levels in these cells (Fig. 8). Half maximal reduction of cAMP was observed at $6 \mu \mathrm{M}(3.5-10 \mu \mathrm{M}, 95 \% \mathrm{CI}) \mathrm{DA}$. TricaDop3 thus inhibits cAMP production, probably via the $G_{\alpha i}$

Table 1

Indication of activation by agonists $(100 \mu \mathrm{M})$ or inhibition by antagonists ( $100 \mu \mathrm{M}$; in presence of $1 \mu \mathrm{M}$ DA) of the TricaDop3 receptor activity in CHO-WTA11 and HEK293 cells. Abbreviations used: DA, dopamine; 6,7-ADTN, ( \pm )-2-amino-6,7 - dihydroxy 1,2,3,4 - tetrahydronaphthalene hydrobromide; 5-MT, 5-methoxytryptamine (5MT), WAY, N-(2-[4-(2-methoxyphenyl)-1-piperazinyl]-ethyl)-N-(2-pyridinyl) cyclohexanecarboxamide. The agonists 5-MT and octopamine showed $\sim 72$ and $49 \%$ of the DA response (indicated as ++ and + ) at $100 \mu \mathrm{M}$ concentration. Antagonists (at concentration of $100 \mu \mathrm{M}$ ) that showed $\sim 40 \%$ inhibition of a $1 \mu \mathrm{M}$ DA response are indicated + , the ones that showed $\sim 60 \%$ inhibition are indicated ++ , antagonists that induced no inhibition are indicated with -.

\begin{tabular}{cll}
\hline & $\begin{array}{l}\text { activation/inhibition } \\
\text { in CHO-WTA11 cells }\end{array}$ & $\begin{array}{l}\text { activation/inhibition } \\
\text { in HEK293 cells }\end{array}$ \\
\hline agonists & & \\
DA & $+++\left(\mathrm{EC}_{50}=0.6 \mu \mathrm{M}\right)$ & $+++\left(\mathrm{IC}_{50}=6 \mu \mathrm{M}\right)$ \\
$6,7-\mathrm{ADTN}$ & $+++\left(\mathrm{EC}_{50}=2.8 \mu \mathrm{M}\right)$ & +++ \\
bromocriptine & $+++\left(\mathrm{EC}_{50}=1.2 \mu \mathrm{M}\right)$ & +++ \\
5-MT & ++ & + \\
tyramine & $++\left(\mathrm{EC}_{50}=60 \mu \mathrm{M}\right)$ & ++ \\
octopamine & + & + \\
antagonists & & - \\
butaclamol & + & - \\
chlorpromazine & + & - \\
flupenthixol & ++ & - \\
ketanserin & - & - \\
methiothepin & - & ++ \\
methysergide & ++ & ++ \\
mianserin & ++ & - \\
prazosin & - & - \\
SB-269970 & - & - \\
WAY-100635 & - & - \\
spiperone & - & \\
yohimbine & + &
\end{tabular}




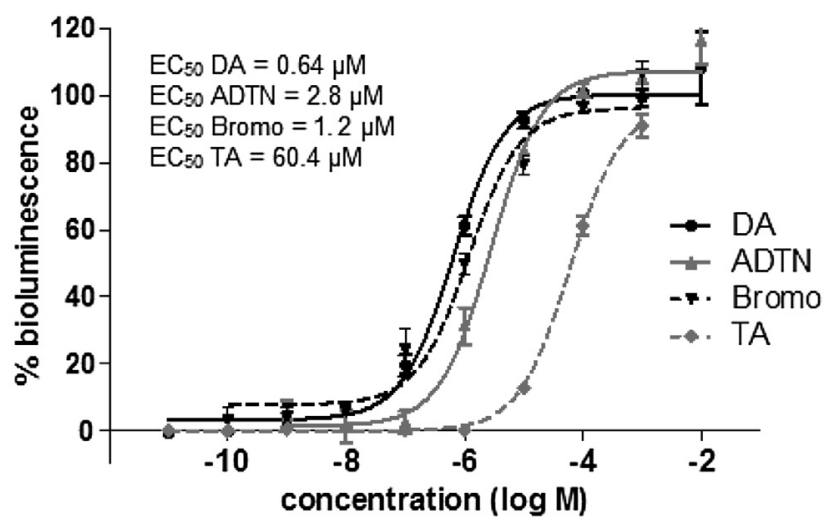

Fig. 4. Dose-response $\left(\mathrm{Ca}^{2+}\right)$ curves of agonists applied to TricaDop3-expressing CHO-WTA11 cells also stably expressing $\mathbf{G}_{\alpha 16}$. Bioluminescence levels measured in blanks were subtracted and the $100 \%$ level is representative for responses obtained using $100 \mu \mathrm{M}$ dopamine alone. Responses to dopamine (DA) were measured six times in duplicate; responses to 6-amino-5,6,7,8-tetrahydronaphthalene-2,3-diol hydrobromide (ADTN) and bromocriptine (Bromo) were measured four times in duplicate and responses to tyramine (TA) were measured twice in duplicate.

protein. Interestingly, at concentrations below $1 \mu \mathrm{M}$, DA enhanced responses to $\mathrm{NKH}-477$, increasing cAMP to a level higher than that recorded in response to $\mathrm{NKH}-477$ alone, with mean responses to $\mathrm{NKH}-477$ alone around $70 \%$ of maximum (Fig. 8). It is also interesting to note that when DA was applied at concentrations greater than $30 \mu \mathrm{M}$, cAMP levels fell below the level detected in the 'blank' measurement: cells expressing TricaDop3 that had not been exposed to either NKH-477 or DA and which are added to medium with IBMX (see $\S 2.8$ ) ('blank', Fig. 8). In blanks, cAMP levels were approximately $20 \%$ higher than in cells exposed to $\mathrm{NKH}-477$ together with high doses of DA (Fig. 8).

The antagonists that were tested initially on DA responses elicited from CHO-WTA11 cells stably expressing apoaequorin and the promiscuous $G_{a 16}$ subunit were tested again to determine their effect on DA-induced decreases in intracellular cAMP levels in TricaDop3-expressing HEK293 cells. As before, the effects of antagonists at a concentration of $100 \mu \mathrm{M}$ were tested against responses to $1 \mu \mathrm{M}$ DA. At this concentration, butaclamol, chlorpromazine, flupenthixol and spiperone failed to block DA-induced decreases in intracellular cAMP levels. Ketanserin, methiothepin, prazosin, SB-

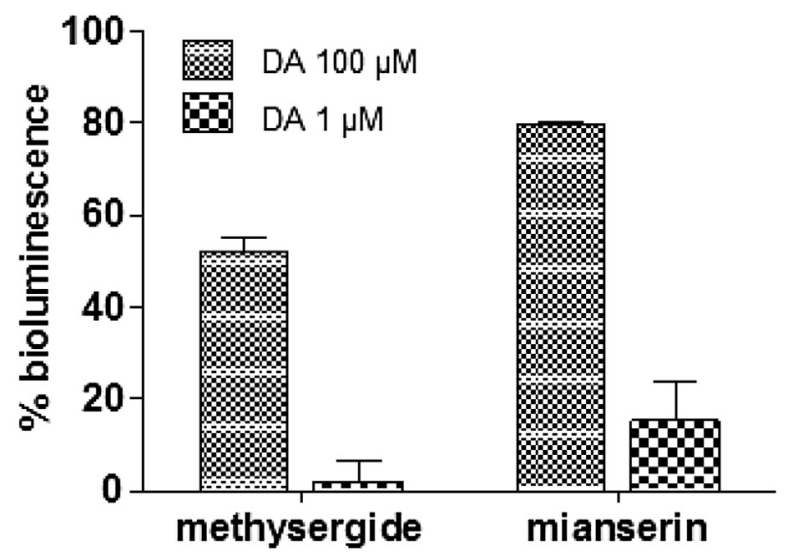

Fig. 5. Activation of TricaDop3 in CHO-WTA11 cells by dopamine $(100 \mu \mathrm{M}, 1 \mu \mathrm{M})$ in the presence of $100 \mu \mathrm{M}$ antagonist. Bioluminescence levels measured in blanks were subtracted and the data are presented relative to responses obtained in the presence of either, $1 \mu \mathrm{M}$ or $100 \mu \mathrm{M}$ dopamine (100\%), as appropriate. The bars represent mean values + SEM. Measurements were performed twice in triplicate. Abbreviation used: DA, dopamine.

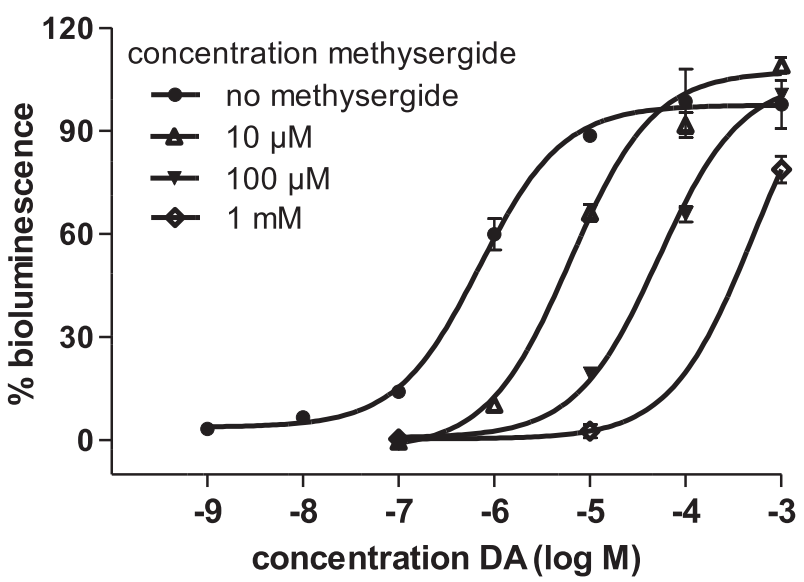

Fig. 6. Effects of methysergide on dopamine (DA) dose-response curves measured in TricaDop3-expressing CHO-WTA11 cells. Bioluminescence levels measured in blanks were subtracted and the data are presented relative to responses obtained using $100 \mu \mathrm{M}$ dopamine alone (100\%). Measurements were performed three times in duplicate. The pA2 value of methysergide is 5.74 .

269970, WAY-100635 and yohimbine were also found to be ineffective at this concentration. However, methysergide and mianserin, the most potent inhibitors of the response in CHO-WTA11 cells, also reduced DA-induced changes in cAMP levels in TricaDop3-expressing HEK293 cells (Table 1, Fig. 9). A high dose $(100 \mu \mathrm{M})$ of all active chemicals was also tested on cells transfected with empty pcDNA3.1 vector and could not induce a signal in these cells (results not shown).

To test whether the presence of TricaDop3 in itself affects intracellular cAMP levels, three different concentrations $(1 \mu \mathrm{g}, 4 \mu \mathrm{g}$ and $8 \mu \mathrm{g}$ ) of pcDNA3.1-TricaDop3 vector were used for transfection of HEK293 cells. For each group of cells, a range of DA concentrations was tested and compared to the response of cells transfected with empty pcDNA3.1 vector. The results of this experiment indeed suggest that the presence of the receptor alters cAMP levels even in the absence of DA. Fig. 10 shows that both in the presence and absence of $\mathrm{NKH}-477$, the higher the concentration of receptor construct used for transfection, the lower the level of cAMP that was detected, prior to the application of DA. We also tested whether the transfection concentration affects the response of the cells to DA. For purposes of comparison, cAMP levels are presented relative to the levels detected in cells transfected with $1 \mu \mathrm{g}$ of TricaDop3,

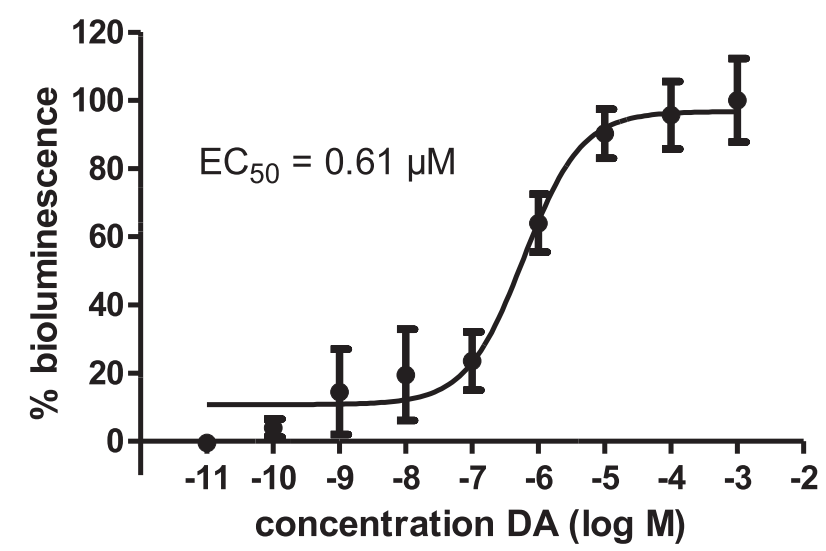

Fig. 7. Dopamine (DA)-induced changes in calcium levels in TricaDop3-expressing CHO-PAM28 cells. Bioluminescence levels measured in blanks were subtracted and the data are presented relative to responses obtained using $100 \mu \mathrm{M}$ dopamine alone (100\%). All measurements were performed four times in duplicate. 


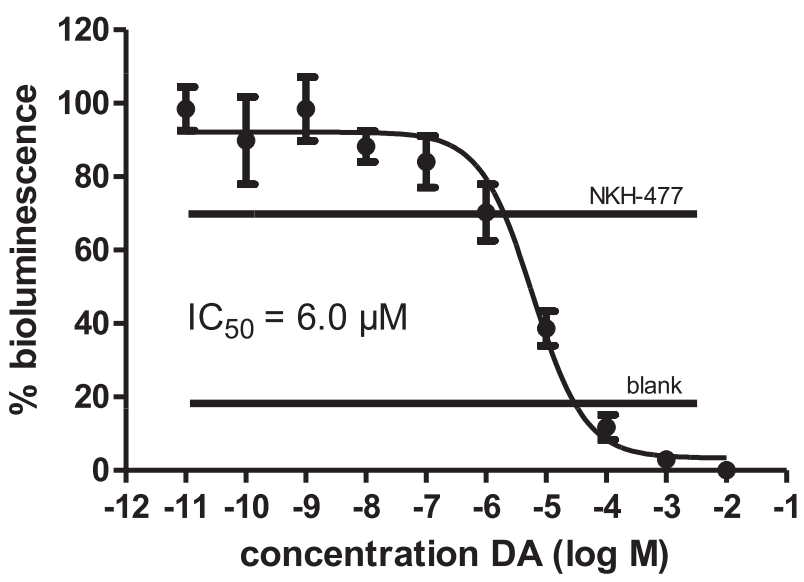

Fig. 8. Dopamine (DA)-induced changes in intracellular cAMP in TricaDop3expressing HEK293 cells measured in the presence of $10 \mu \mathrm{M}$ NKH-477. The $100 \%$ level represents the activation of the receptor by $1 \mathrm{nM}$ of dopamine in the presence of $10 \mu \mathrm{M}$ of NKH-477 (a forskolin analogue) and $0 \%$ represents the level of activation of the receptor by $10 \mathrm{mM}$ of dopamine in the presence of $10 \mu \mathrm{M}$ of NKH- 477 . The measurements were performed six times in duplicate. Horizontal lines are used to indicate the levels of cAMP detected in the presence of $10 \mu \mathrm{M} N K H-477$ but without DA ('NKH477'), and in the absence of both NKH-477 and DA ('blank').

and examined in the presence of NKH-477 and 1 nM DA. $\mathrm{EC}_{50}$ values obtained using the three different transfection concentrations do not differ significantly and in all cells, responses to DA at the highest concentration tested are equally low (Fig. 11).

\section{Discussion}

\subsection{Sequence information}

In this study we describe the cloning of cDNA encoding a dopamine Dop3 receptor from T. castaneum. The hydrophobicity profile revealed seven putative membrane-spanning segments, a structural feature shared by all members of the GPCR superfamily. These receptors are commonly glycosylated, a posttranslational modification involved in receptor stability, turnover and targeting

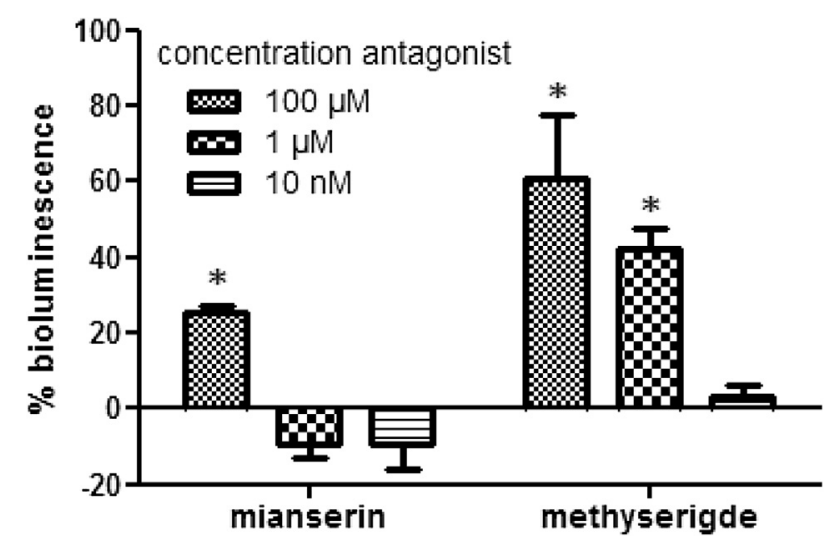

Fig. 9. Effects of 3 different concentrations of the antagonists, mianserin and methysergide on responses to DA $(100 \mu \mathrm{M})$ in TricaDop3-expressing HEK293 cells treated with $10 \mu \mathbf{M}$ NKH-477. The bars represent the bioluminescence as a result of changes in NKH-477 $(10 \mu \mathrm{M})$ induced intracellular cAMP levels in presence of $100 \mu \mathrm{M}$ dopamine and different concentrations $(10 \mathrm{nM}, 1 \mu \mathrm{M}$ or $100 \mu \mathrm{M})$ of antagonist (mianserin or methysergide) + SEM. The $100 \%$ level represents the bioluminescence measured in the presence of $1 \mathrm{nM}$ of dopamine and $10 \mu \mathrm{M} \mathrm{NKH}-477$, and $0 \%$ represents the bioluminescence in the presence of $100 \mu \mathrm{M}$ DA and $10 \mu \mathrm{M}$ NKH-477. $100 \mu \mathrm{M}$ of mianserin and concentrations higher than $1 \mu \mathrm{M}$ of methysergide significantly reduce the function of DA. The measurements were performed in duplicate.

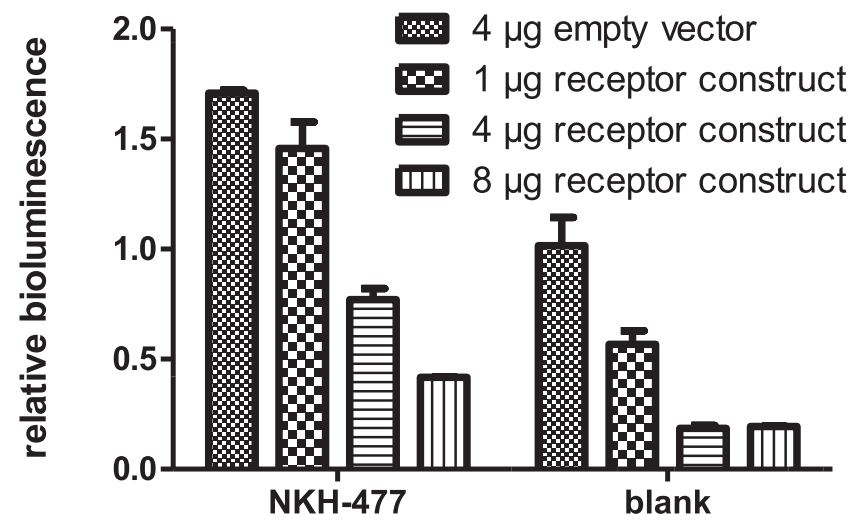

Fig. 10. Effect on cAMP levels of using different expression vector (with the TricaDop3) concentrations for transfection of HEK293 cells in absence of dopamine (DA). The bars represent the bioluminescence measured in cells transfected with empty vector or different concentrations of the TricaDop3 expression vector in the presence or absence of $10 \mu \mathrm{M} \mathrm{NKH}-477$. Higher concentrations of receptor construct used for transfection led to lower cAMP levels. The measurements were performed in triplicate.

to the membrane (Clagett-Dame and McKelvy, 1989). TricaDop3 has eight Asn residues at its $\mathrm{N}$-terminal end for potential glycosylation. Posttranslational phosphorylation of residues in the third intracellular loop and C-terminus of the receptors is believed to be involved in receptor desensitisation (Butcher et al., 2012). TricaDop3 contains one Thr and four Ser residues for phosphorylation by PKC. Several sequence characteristics necessary for dopamine binding are present. Of particular note is a series of Ser residues in TM5 that are supposed to interact with the catecholamine ring of DA (Pollock et al., 1992; Strader et al., 1989).

Amino acid sequence similarity was highest with insect Dop3 receptors. Indeed, similarities with Dop3 orthologues from D. melanogaster and A. mellifera are high, reaching more than $96 \%$ within the transmembrane regions (Fig. 1). Such high percentages are comparable with similarities between other biogenic amine receptor orthologues in insects (Vleugels et al., 2013, 2014).

\subsection{Transcript level study}

Tricadop3 transcript levels are high in the central nervous tissue of the head, namely the central brain and the optic lobes. This is in accordance with the general perception of a neurotransmitter role for DA and is consistent with previous studies in insects. In the fruit

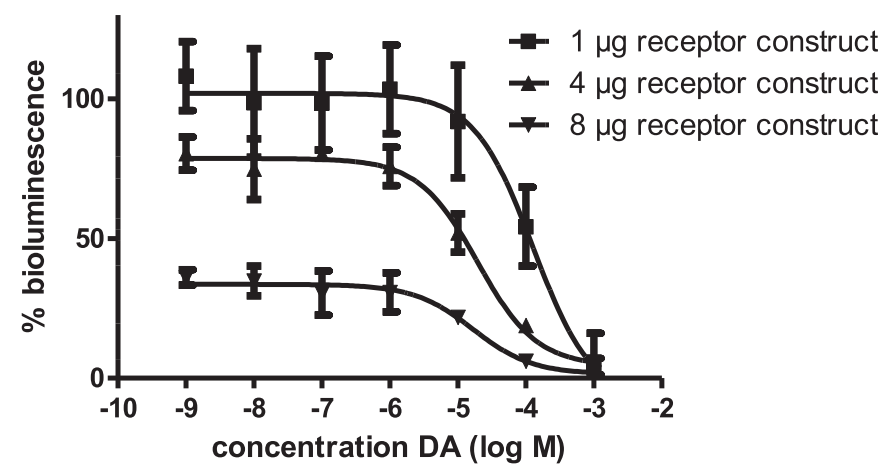

Fig. 11. Effect on NKH-477 stimulated cAMP levels of different expression vector concentrations for transfection of HEK293 cells in presence of different amounts of dopamine (DA). The 100\% level represents the cAMP level of cells transfected with $1 \mu \mathrm{g}$ of receptor construct and exposed to $10 \mu \mathrm{M}$ of $\mathrm{NKH}-477$. The $0 \%$ level represents the level of activation of the receptor by $10 \mathrm{mM}$ of dopamine in the presence of $10 \mu \mathrm{M}$ of NKH-477. The measurements were performed in triplicate. 
fly, DromeDop3 is highly expressed in the head and brain, and an important role in early neural development and central nervous system function has been suggested (Wiemerslage et al., 2013); FlyAtlas, URL: http://www.flyatlas.org). Functional data in T. castaneum were obtained using RNA interference (RNAi), which induced high mortality during the larval stage and impaired moult to the pupal stage (Bai et al., 2011). TricaDop3 is therefore suggested to play an important role during larval growth and development, perhaps by modulating neural development and locomotor activity as reported in D. melanogaster (Draper et al., 2007; Wiemerslage et al., 2013). Expression in the brain is also in line with Dop3 expression in the honey bee. In situ hybridisation analysis of ApimeDop3 in the brain of adult honey bees showed expression in the Kenyon cells of the mushroom body. Expression of this receptor was also observed in cells around the antennal lobes and cells associated with the optic lobes. As a result, ApimeDop3 is suggested to play a role in the processing of information of sensory pathways in the brain (Beggs et al., 2005).

\subsection{Receptor pharmacology}

Pharmacological analysis identified bromocriptine and 6,7ADTN as effective agonists of TricaDop3 in CHO-WTA11 cells, both with a potency and efficacy comparable to DA. Also in ApimeDop3 expressing HEK293 cells, bromocriptine induced a decrease in cAMP equally large as DA (10 $\mu \mathrm{M})$ (Beggs et al., 2005). On DromeDop3, bromocriptine was more potent than DA at decreasing intracellular cAMP levels (with $\mathrm{EC}_{50}$ values varying from 1.4 to $2.1 \mathrm{nM}$ for bromocriptine, and $0.3-0.4 \mu \mathrm{M}$ for DA) (Hearn et al., 2002). Both DA and bromocriptine at maximally effective concentrations induced a more than tenfold decrease in luciferase activity (vs. basal). Bromocriptine thus seems to be a potent and effective agonist for insect Dop3 receptors. Bromocriptine is reported to have minor agonist activity on DromeDop2 (Reale et al., 1997a), and no agonist activity was measured on Dop2 from Periplaneta americana (Troppmann et al., 2014). It may thus be a good candidate to pharmacologically distinguish D2-like receptors from D1-like receptors and INDRs in insects. The agonist 6,7-ADTN has been shown to have some activity on DromeDop3, but also on other DA receptor subtypes in D. melanogaster, A. mellifera and P. americana (Mustard et al., 2003; Sugamori et al., 1995; Troppmann et al., 2014). An agonist of 5-HT-receptors, 5-MT, (Thamm et al., 2010; Troppmann et al., 2010; Vleugels et al., 2013, 2014) also induced considerable receptor activation.

Because of the suggested phylogenetic relationship between insect Dop3 receptors and tyramine receptors (Beggs et al., 2011), we also tested tyramine on our receptor. However, tyramine was much less potent in activating TricaDop3 than DA (Figs. 3 and 4). Also in A. mellifera high concentrations $(>10 \mu \mathrm{M})$ of tyramine were needed to decrease intracellular cAMP levels (Beggs et al., 2005). However, tyramine has been found to have a relatively high potency on DromeDop3 ( $\mathrm{EC}_{50}$ around $10 \mu \mathrm{M}$ ), as well as some other biogenic amines such as serotonin and (nor)epinephrine (Hearn et al., 2002).

For insect Dop3 receptors, almost no pharmacological data are available concerning potent antagonists. A high concentration of flupenthixol, an antagonist known to inhibit mammalian dopamine (D1-D5), serotonin (5-HT2), adrenaline $(\alpha 1)$, and histamine $(\mathrm{H} 1)$ receptors, as well as insect Dop1 and Dop2 receptors (Blenau et al., 1998; Han et al., 1996; Hearn et al., 2002; Mustard et al., 2003, 2005; Reale et al., 1997a; Srivastava et al., 2005), was able to inhibit the DA-induced reduction of cAMP levels in DromeDop3expressing cells (Hearn et al., 2002), but was not active on ApimeDop3 (Beggs et al., 2011) or on TricaDop3 when expressed in HEK293 cells. However, when we expressed the TricaDop3 receptor in CHO-WTA11 cells stably expressing aequorin and the promiscuous $\mathrm{G}_{\alpha 16}$ subunit, $100 \mu \mathrm{M}$ flupenthixol was able to inhibit the DA signalling. This was also the case for butaclamol, chlorpromazine and yohimbine. Either the type of assay influences the outcome or possibly these antagonists only block the $\mathrm{Ca}^{2+}$ signalling and not the cAMP signalling.

We identified methysergide, known as a non-selective antagonist of mammalian 5-HT receptors, as a potent antagonist for TricaDop3. It showed characteristics of competitive inhibition in the presence of DA in CHO-WTA11 cells. Röser et al. (2012) have shown that, in the blowfly, methysergide activates $5-\mathrm{HT}_{7}$ but inhibits 5 $\mathrm{HT}_{2 \alpha}$-mediated responses. In the honey bee, methysergide displays high potency at $5-\mathrm{HT}_{2 \alpha}$ but does not block $5-\mathrm{HT}_{2 \beta}$ (Thamm et al., 2013). It was also shown to be a relatively potent competitive inhibitor of 5 - $\mathrm{HT}_{1}$-type and 5 - $\mathrm{HT}_{7}$-type serotonin receptors of T. castaneum (Vleugels et al., 2013, 2014).

\subsection{Signalling properties}

When looking at the downstream coupling of the receptor, TricaDop3 was able to activate a calcium signalling pathway, as well as to decrease the intracellular levels of cAMP. The concentrations needed to achieve the half-maximal calcium signal in the two $\mathrm{CHO}$ cell lines used, were around $0.6 \mu \mathrm{M}$. These $\mathrm{EC}_{50}$ values are similar in magnitude to those reported for cAMP signalling of DA receptors from D. melanogaster and A. mellifera (Han et al., 1996; Hearn et al., 2002; Mustard et al., 2005; Sugamori et al., 1995). However, the IC 50 value in TricaDop3-expressing HEK293 cells was about 10 times higher $(6 \mu \mathrm{M})$. This might indicate that this receptor is more potent in signalling via calcium, than in inhibiting the cAMP pathway. However, the use of different cell types might also be responsible, at least in part, for these differences in $\mathrm{EC}_{50} / \mathrm{IC}_{50}$ values, or even for differential second messenger coupling. Indeed, different cell lines may differ in the number of receptors expressed at the plasma membrane, in the levels of interacting proteins (including different $G$ proteins), in the effector systems generating second messengers and/or in cellular metabolism. Also, possible differences between effects observed in cultured cell lines and intracellular processes occurring within the in vivo context of an organism should be taken into account.

In vertebrates, $D 2$-like receptors are coupled to $\mathrm{G}_{\mathrm{i} / \mathrm{o}}$ proteins and negatively regulate AC activity, resulting in a decrease of cAMP production and subsequently decreased PKA activity (Enjalbert and Bockaert, 1983; Kebabian and Calne, 1979; Kebabian and Greengard, 1971; Missale et al., 1998). The Dop3 receptors from $D$. melanogaster and A. mellifera were also shown to induce a decrease in intracellular cAMP levels in vitro (Beggs et al., 2005; Beggs and Mercer, 2009; Hearn et al., 2002). Our study also showed that Dop3 receptor activation can also influence intracellular calcium levels. This response might be attributed to $G_{\alpha q}$ proteins, but as well to $G_{\beta \gamma}$ signalling. Indeed, Clark and Baro (2007) surprisingly showed an increase in intracellular cAMP levels upon application of DA to HEK293 cells expressing Dop3 from A. mellifera or the lobster Panulirus interruptus. They showed that the P. interruptus Dop3 receptor stimulates $\mathrm{G}_{\mathrm{i} / \mathrm{o}}$ protein activity, leading to the activation of two pathways: a $\mathrm{G}_{\alpha}$-mediated inhibition of AC and a $G_{\beta \gamma}$-mediated activation of phospholipase $C$ leading to an increase in cAMP. Also mammalian D2-like receptors are able to regulate $A C$ activity via $\mathrm{G}_{\beta \gamma}$-mediated activation of phospholipase $C$ (Tsu and Wong, 1996). In addition, mammalian D2-like receptors can modulate intracellular calcium levels by acting on ion channels or by triggering the release of intracellular calcium stores, partly due to $G_{\beta \gamma}$ activity (Beaulieu \& Gainetdinov, 2011; HernandezLopez et al., 2000; Missale et al., 1998; Nishi et al., 1997; Yan et al., 1997). 
The TricaDop3 receptor shows a number of other interesting features. First, trace amounts of DA appear to enhance responses of this receptor to NKH-477, elevating cAMP in the cells to levels above those detected in response to NKH-477 alone (Fig. 8). Basal levels of cAMP, on the other hand, were affected by the concentration of pcDNA3.1-TricaDop3 transfected into the cells; the higher the concentration of receptor construct the lower the basal cAMP levels recorded in the cells (Figs. 10 and 11). Previous studies on Dop3 receptors report similar features (Beggs et al., 2005; Clark and Baro, 2007). One possible explanation could be that trace amounts of DA cause a conformational change in the receptor protein that affects receptor function, leading to increases in cAMP levels in response to receptor activation. In the presence of higher DA concentrations, the receptor may assume a different conformation and as a result, receptor activation leads to a decline in levels of cAMP.

Interestingly, receptors with dual coupling properties can display agonist-dependent functional differences, as was first shown for biogenic amine GPCRs of Drosophila (Reale et al., 1997a; Robb et al., 1994). Indeed, different agonists/antagonists may induce different conformational changes of a receptor. Different receptor conformations in their turn can facilitate coupling to a specific effector protein thereby favouring a particular downstream signalling pathway. In insect neuropeptide receptors, such agonistdependent, receptor-mediated differences in downstream coupling behaviour have been suggested to contribute to the physiological fine-tuning by naturally occurring variants of a given peptide family (Dillen et al., 2013; Poels et al., 2004, 2005).

It is equally interesting that when DA was applied at concentrations greater than $30 \mu \mathrm{M}$, cAMP levels fell below the level detected in TricaDop3-expressing cells prior to applying either NKH-477 or DA (blanks, Fig. 8). At the highest DA concentrations tested, cAMP levels were reduced to minimum levels regardless of the concentration of receptor construct used for the transfection (Fig. 11).

Further phylogenetic and pharmacological studies will be needed to further clarify how the different metazoan biogenic amine receptors are related to each other and how they can be pharmacologically distinguished from one another. This information will enable functional experiments to be undertaken with drugs that show receptor-selective activity, which may lead to the development of a novel generation of insect pest control agents (Verlinden et al., 2014)

\section{Acknowledgements}

We are grateful to Joost Van Duppen for technical support and Kristel Vuerinckx for help with the dissections and cDNA sample preparations. We would like to thank Marc Parmentier (Free University of Brussels, Belgium) and Michel Detheux (Euroscreen S.A., Belgium) for providing CHO-WTA11 and CHO-PAM28 cells and Andrew Mercer (University of Otago, New Zealand) for providing HEK293 cells. We would also like to thank the anonymous reviewers for their helpful comments to improve the manuscript.

This work was supported by the Interuniversity Attraction Poles programs (Belgian Science Policy Grant (P7/40)), the Research Foundation of Flanders (FWO-Flanders), the K.U. Leuven Research Foundation (GOA/11/02), the Institute for Innovation by Science and Technology (IWT), and a grant to AM from the Department of Zoology (Otago) Research Fund (FZ-63).

\section{Appendix A. Supplementary data}

Supplementary data related to this article can be found at http:// dx.doi.org/10.1016/j.ibmb.2014.11.002.

\section{References}

Andre, V.M., Cepeda, C., Levine, M.S., 2010. Dopamine and glutamate in Huntington's disease: a balancing act. CNS Neurosci. Ther. 16, 163-178.

Ares-Santos, S., Granado, N., Moratalla, R., 2013. The role of dopamine receptors in the neurotoxicity of methamphetamine. J. Intern. Med. 273, 437-453.

Bai, H., Zhu, F., Shah, K., Palli, S.R., 2011. Large-scale RNAi screen of G proteincoupled receptors involved in larval growth, molting and metamorphosis in the red flour beetle. BMC Genomics 12.

Balfanz, S., Strünker, T., Frings, S., Baumann, A., 2005. A family of octopamine receptors that specifically induce cyclic AMP production or $\mathrm{Ca}^{2+}$ release in Drosophila melanogaster. J. Neurochem. 93, 440-451.

Ballesteros, J.A., Weinstein, H., 1995. Integrated methods for the construction of three-dimensional models and computational probing of structure-function relations in G protein-coupled receptors. Methods Neurosci. 25, 366-428.

Barak, L.S., Tiberi, M., Freedman, N.J., Kwatra, M.M., Lefkowitz, R.J., Caron, M.G., 1994. A highly conserved tyrosine residue in G protein-coupled receptors is required for agonist-mediated beta(2)-adrenergic receptor sequestration. J. Biol. Chem. 269, 2790-2795.

Barbas, D., Zappulla, J.P., Angers, S., Bouvier, M., Mohamed, H.A., Byrne, J.H. Castelluci, V.F., DesGroseillers, L., 2006. An Aplysia dopamine 1-like receptor: molecular and functional characterization. J. Neurochem. 96, 414-427.

Bayliss, A., Roselli, G., Evans, P.D., 2013. A comparison of the signalling properties of two tyramine receptors from Drosophila. J. Neurochem. 125, 37-48.

Beaulieu, J.M., Gainetdinov, R.R., 2011. The physiology, signaling, and pharmacology of dopamine receptors. Pharmacol. Rev. 63, 182-217.

Beeman, R.W., Haas, S., Friesen, K., 2009. Beetle Wrangling Tips. (An Introduction to the Care and Handling of Tribolium castaneum). http://bru.gmprc.ksu.edu/proj/ tribolium/wrangle.asp (last modified 02.28.12.).

Beggs, K.T., Mercer, A.R., 2009. Dopamine receptor activation by honey bee queen pheromone. Curr. Biol. 19, 1206-1209.

Beggs, K.T., Hamilton, I.S., Kurshan, P.T., Mustard, J.A., Mercer, A.R., 2005. Characterization of a D2-like dopamine receptor (AmDOP3) in honey bee, Apis mellifera. Insect Biochem. Mol. Biol. 35, 873-882.

Beggs, K.T., Tyndall, J.D., Mercer, A.R., 2011. Honey bee dopamine and octopamine receptors linked to intracellular calcium signaling have a close phylogenetic and pharmacological relationship. PLOS ONE 6, e26809.

Birse, R.T., Johnson, E.C., Taghert, P.H., Nässel, D.R., 2006. Widely distributed Drosophila G-protein-coupled receptor (CG7887) is activated by endogenous tachykinin-related peptides. J. Neurobiol. 66, 33-46.

Blanpain, C., Migeotte, I., Lee, B., Vakili, J., Doranz, B.J., Govaerts, C., Vassart, G., Doms, R.W., Parmentier, M., 1999. CCR5 binds multiple CC-chemokines: MCP-3 acts as a natural antagonist. Blood 94, 1899-1905.

Blenau, W., Erber, J., Baumann, A., 1998. Characterization of a dopamine D1 receptor from Apis mellifera: cloning, functional expression, pharmacology, and mRNA localization in the brain. J. Neurochem. 70, 15-23.

Bockaert, J., Pin, J.P., 1999. Molecular tinkering of G protein-coupled receptors: an evolutionary success. EMBO J. 18, 1723-1729.

Borroto-Escuela, D.O., Romero-Fernandez, W., Garcia-Negredo, G., Correia, P.A., Garriga, P., Fuxe, K., Ciruela, F., 2011. Dissecting the conserved NPxxY motif of the M3 muscarinic acetylcholine receptor: critical role of Asp-7.49 for receptor signaling and multiprotein complex formation. Cell. Physiol. Biochem. 28, 1009-1022.

Brough, S.J., Shah, P., 2009. Use of aequorin for G protein-coupled receptor hit identification and compound profiling. Methods Mol. Biol. 552, 181-198.

Buse, J., Schoenefeld, K., Munchau, A., Roessner, V., 2013. Neuromodulation in Tourette syndrome: dopamine and beyond. Neurosci. Biobehav. Rev. 37, 1069-1084.

Butcher, A.J., Kong, K.C., Prihandoko, R., Tobin, A.B., 2012. Physiological role of Gprotein coupled receptor phosphorylation. Handb. Exp. Pharmacol. 79-94.

Callier, S., Snapyan, M., Le Crom, S., Prou, D., Vincent, J.D., Vernier, P., 2003. Evolution and cell biology of dopamine receptors in vertebrates. Biol. Cell. 95, 489-502.

Cardinaud, B., Gilbert, J.M., Liu, F., Sugamori, K.S., Vincent, J.D., Niznik, H.B., Vernier, P., 1998. Evolution and origin of the diversity of dopamine receptors in vertebrates. Adv. Pharmacol. 42, 956-940.

Chung, F.Z., Wang, C.D., Potter, P.C., Venter, J.C., Fraser, C.M., 1988. Site-directed mutagenesis and continuous expression of human beta-adrenergic receptors. Identification of a conserved aspartate residue involved in agonist binding and receptor activation. J. Biol. Chem. 263, 4052-4055.

Clagett-Dame, M., McKelvy, J.F., 1989. N-linked oligosaccharides are responsible for rat striatal dopamine D2 receptor heterogeneity. Arch. Biochem. Biophys. 274, 145-154.

Clark, M.C., Baro, D.J., 2007. Arthropod D2 receptors positively couple with cAMP through the Gi/o protein family. Comp Biochem. Physiol. B Biochem. Mol. Biol. 146, 9-19.

Cousins, D.A., Butts, K., Young, A.H., 2009. The role of dopamine in bipolar disorder. Bipolar Disord. 11, 787-806.

Dillen, S., Zels, S., Verlinden, H., Spit, J., Van Wielendaele, P., Vanden Broeck, J., 2013. Functional characterization of the short neuropeptide $F$ receptor in the desert locust, Schistocerca gregaria. PLOS ONE 8, e53604.

Dixon, R.A., Sigal, I.S., Candelore, M.R., Register, R.B., Scattergood, W., Rands, E., Strader, C.D., 1987. Structural features required for ligand binding to the betaadrenergic receptor. EMBO J. 6, 3269-3275. 
Draper, I., Kurshan, P.T., McBride, E., Jackson, F.R., Kopin, A.S., 2007. Locomotory activity is related by D2-like receptors in Drosophila: an anatomic and functional analysis. Dev. Neurobiol. 17, 378-393.

Emsley, R., Chiliza, B., Asmal, L., Harvey, B.H., 2013. The nature of relapse in schizophrenia. BMC Psychiatry 13, 50.

Enjalbert, A., Bockaert, J., 1983. Pharmacological characterization of the D2 dopamine receptor negatively coupled with adenylate cyclase in rat anterior pituitary. Mol. Pharmacol. 23, 576-584.

Evans, P.D., Maqueira, B., 2005. Insect octopamine receptors: a new classification scheme based on studies of cloned Drosophila G-protein coupled receptors. Invert. Neurosci. 5, 111-118.

Evans, P.D., Bayliss, A., Reale, V., 2014. GPCR-mediated rapid, non-genomic actions of steroids: comparisons between DmDopEcR and GPER1 (GPR30). Gen. Comp. Endocrinol. 195, 157-163.

Feng, G., Hannan, F., Reale, V., Hon, Y.Y., Kousky, C.T., Evans, P.D., Hall, L.M., 1996 Cloning and functional characterization of a novel dopamine receptor from Drosophila melanogaster. J. Neurosci. 16, 3925-3933.

Fraser, C.M., 1989. Site-directed mutagenesis of beta-adrenergic receptors. Identification of conserved cysteine residues that independently affect ligand binding and receptor activation. J. Biol. Chem. 264, 9266-9270.

Fraser, C.M., Chung, F.Z., Wang, C.D., Venter, J.C., 1988. Site-directed mutagenesis of human beta-adrenergic receptors: substitution of aspartic acid-130 by asparagine produces a receptor with high-affinity agonist binding that is uncoupled from adenylate cyclase. Proc. Natl. Acad. Sci. U. S. A. 85, 5478-5482.

Fritze, O., Filipek, S., Kuksa, V., Palczewski, K., Hofmann, K.P., Ernst, O.P., 2003. Role of the conserved $\operatorname{NPxxY}(\mathrm{x}) 5,6 \mathrm{~F}$ motif in the rhodopsin ground state and during activation. Proc. Natl. Acad. Sci. U. S. A. 100, 2290-2295.

Gales, C., Kowalski-Chauvel, A., Dufour, M.N., Seva, C., Moroder, L., Pradayrol, L. Vaysse, N., Fourmy, D., Silvente-Poirot, S., 2000. Mutation of Asn-391 within the conserved NPXXY motif of the cholecystokinin B receptor abolishes Gq protein activation without affecting its association with the receptor. J. Biol. Chem. 275, $17321-17327$.

Gazewood, J.D., Richards, D.R., Clebak, K., 2013. Parkinson disease: an update. Am. Fam. Physician 87, 267-273.

Gerber, S., Krasky, A., Rohwer, A., Lindauer, S., Closs, E., Rognan, D., Gunkel, N., Selzer, P.M., Wolf, C., 2006. Identification and characterisation of the dopamine receptor II from the cat flea Ctenocephalides felis (CfDopRII). Insect Biochem. Mol. Biol. 36, 749-758.

Gerhardt, C.C., Leysen, J.E., Planta, R.J., Vreugdenhil, E., van Heerikhuizen, H., 1996 Functional characterisation of a 5-HT2 receptor cDNA cloned from Lymnaea stagnalis. Eur. J. Pharmacol. 311, 249-258.

Gether, U., 2000. Uncovering molecular mechanisms involved in activation of $\mathrm{C}$ protein-coupled receptors. Endocr. Rev. 21, 90-113.

Gotzes, F., Balfanz, S., Baumann, A., 1994. Primary structure and functional characterization of a Drosophila dopamine receptor with high homology to human D1/5 receptors. Recept. Channels 2, 131-141.

Gripentrog, J.M., Jesaitis, A.J., Miettinen, H.M., 2000. A single amino acid substitution (N297A) in the conserved NPXXY sequence of the human $\mathrm{N}$-formyl peptide receptor results in inhibition of desensitization and endocytosis, and a dosedependent shift in p42/44 mitogen-activated protein kinase activation and chemotaxis. Biochem. J. 352 (Pt 2), 399-407.

Han, K.A., Millar, N.S., Grotewiel, M.S., Davis, R.L., 1996. DAMB, a novel dopamine receptor expressed specifically in Drosophila mushroom bodies. Neuron 16 1127-1135.

Hauser, F., Cazzamali, G., Williamson, M., Blenau, W., Grimmelikhuijzen, C.J.P. 2006 A review of neurohormone GPCRs present in the fruitfly Drosophila melanogaster and the honey bee Apis mellifera. Prog. Neurobiol. 80, 1-19.

Hauser, F., Cazzamali, G., Williamson, M., Park, Y., Li, B., Tanaka, Y., Predel, R. Neupert, S., Schachtner, J., Verleyen, P., Grimmelikhuijzen, C.J., 2008. A genomewide inventory of neurohormone GPCRs in the red flour beetle Tribolium castaneum. Front. Neuroendocrinol 29, 142-165.

Hearn, M.G., Ren, Y., McBride, E.W., Reveillaud, I., Beinborn, M., Kopin, A.S., 2002 A Drosophila dopamine 2-like receptor: molecular characterization and identification of multiple alternatively spliced variants. Proc. Natl. Acad. Sci. U. S. A. 99, 14554-14559.

Hernandez-Lopez, S., Tkatch, T., Perez-Garci, E., Galarraga, E., Bargas, J., Hamm, H. Surmeier, D.J., 2000. D2 dopamine receptors in striatal medium spiny neurons reduce L-type $\mathrm{Ca}^{2+}$ currents and excitability via a novel PLC[beta]1-IP3calcineurin-signaling cascade. J. Neurosci. 20, 8987-8995.

Ho, B.Y., Karschin, A., Branchek, T., Davidson, N., Lester, H.A., 1992. The role of conserved aspartate and serine residues in ligand binding and in function of the 5-HT1A receptor: a site-directed mutation study. FEBS Lett. 312, $259-262$.

Huang, S.E., 2003. Construction of a sequence motif characteristic of aminergic G protein-coupled receptors. Protein Sci. 12, 1360-1367.

Humphries, M.A., Mustard, J.A., Hunter, S.J., Mercer, A., Ward, V., Ebert, P.R., 2003. Invertebrate D2 type dopamine receptor exhibits age-based plasticity of expression in the mushroom bodies of the honeybee brain. J. Neurobiol. 55, $315-330$.

Johnson, E.C., Bohn, L.M., Taghert, P.H., 2004. Drosophila CG8422 encodes a functional diuretic hormone receptor. J. Exp. Biol. 207, 743-748.

Kalatskaya, I., Schussler, S., Blaukat, A., Muller-Esterl, W., Jochum, M., Proud, D. Faussner, A., 2004. Mutation of tyrosine in the conserved NPXXY sequence leads to constitutive phosphorylation and internalization, but not signaling, of the human B2 bradykinin receptor. J. Biol. Chem. 279, 31268-31276.
Karnik, S.S., Khorana, H.G., 1990. Assembly of functional rhodopsin requires a disulfide bond between cysteine residues 110 and 187. J. Biol. Chem. 265, $17520-17524$.

Karnik, S.S., Sakmar, T.P., Chen, H.B., Khorana, H.G., 1988. Cysteine residues 110 and 187 are essential for the formation of correct structure in bovine rhodopsin. Proc. Natl. Acad. Sci. U. S. A. 85, 8459-8463.

Katoh, K., Misawa, K., Kuma, K., Miyata, T., 2002. MAFFT: a novel method for rapid multiple sequence alignment based on fast Fourier transform. Nucl. Acids Res. 30, 3059-3066.

Katoh, K., Kuma, K., Toh, H., Miyata, T., 2005. MAFFT version 5: improvement in accuracy of multiple sequence alignment. Nucl. Acids Res. 33, 511-518.

Kebabian, J.W., Calne, D.B., 1979. Multiple receptors for dopamine. Nature 277, 93-96.

Kebabian, J.W., Greengard, P., 1971. Dopamine-sensitive adenyl cyclase: possible role in synaptic transmission. Science 174, 1346-1349.

Kenakin, T.P., 1982. The schild regression in the process of receptor classification. Can. J. Physiol. Pharmacol. 60, 249-265.

Kim, H.S., Murphy, T., Xia, J., Caragea, D., Park, Y., Beeman, R.W., Lorenzen, M.D., Butcher, S., Manak, J.R., Brown, S.J., 2010. BeetleBase in 2010: revisions to provide comprehensive genomic information for Tribolium castaneum. Nucl. Acids Res. 38, D437-D442.

Kroeze, W.K., Kristiansen, K., Roth, B.L., 2002. Molecular biology of serotonin receptors structure and function at the molecular level. Curr. Top. Med. Chem. 2, $507-528$

Marshall, R.D., 1974. The nature and metabolism of the carbohydrate-peptide linkages of glycoproteins. Biochem. Soc. Symp. 40, 17-26.

McDonald, P.W., Jessen, T., Field, J.R., Blakely, R.D., 2006. Dopamine signaling architecture in Caenorhabditis elegans. Cell. Mol. Neurobiol. 26, 593-618.

Meyer, J.M., Ejendal, K.F., Watts, V.J., Hill, C.A., 2011. Molecular and pharmacological characterization of two D(1)-like dopamine receptors in the Lyme disease vector, Ixodes scapularis. Insect Biochem. Mol. Biol. 41, 563-571.

Milligan, G., Marshall, F., Rees, S., 1996. Ga16 as a universal G protein adaptor: implications for agonist screening strategies. Trends Pharmacol. Sci. 17, 235-237.

Missale, C., Nash, S.R., Robinson, S.W., Jaber, M., Caron, M.G., 1998. Dopamine receptors: from structure to function. Physiol. Rev. 78, 189-225.

Mitsumasu, K., Ohta, H., Tsuchihara, K., Asaoka, K., Ozoe, Y., Niimi, T., Yamashita, O., Yaginuma, T., 2008. Molecular cloning and characterization of cDNAs encoding dopamine receptor-1 and -2 from brain-suboesophageal ganglion of the silkworm, Bombyx mori. Insect Mol. Biol. 17, 185-195.

Mustard, J.A., Blenau, W., Hamilton, I.S., Ward, V.K., Ebert, P.R., Mercer, A.R., 2003. Analysis of two D1-like dopamine receptors from the honey bee Apis mellifera reveals agonist-independent activity. Brain Res. Mol. Brain Res. 113, 67-77.

Mustard, J.A., Beggs, K.T., Mercer, A.R., 2005. Molecular biology of the invertebrate dopamine receptors. Arch. Insect Biochem. Physiol. 59, 103-117.

Nishi, A., Snyder, G.L., Greengard, P., 1997. Bidirectional regulation of DARPP-32 phosphorylation by dopamine. J. Neurosci. 17, 8147-8155.

Noda, K., Saad, Y., Graham, R.M., Karnik, S.S., 1994. The high-affinity state of the beta 2 -adrenergic receptor requires unique interaction between conserved and nonconserved extracellular loop cysteine. J. Biol. Chem. 269, 6743-6752.

Offermans, S., Simon, M.I., 1995. G $\alpha 15$ and G $\alpha 16$ couple a wide variety of receptors to phospholipase C. J. Biol. Chem. 25, 15175-15180.

Poels, J., Suner, M.M., Needham, M., Torfs, H., De Rijck, J., De Loof, A., Dunbar, S.J., Vanden Broeck, J., 2001. Functional expression of a locust tyramine receptor in murine erythroleukaemia cells. Insect Mol. Biol. 10, 541-548.

Poels, J., Van Loy, T., Franssens, V., Detheux, M., Nachman, R.J., Oonk, H.B., Akerman, K.E., Vassart, G., Parmentier, M., De Loof, A., Torfs, H., Vanden Broeck, J., 2004. Substitution of conserved glycine residue by alanine in natural and synthetic neuropeptide ligands causes partial agonism at the stomoxytachykinin receptor. J. Neurochem. 90, 472-478.

Poels, J., Nachman, R.J., Akerman, K.E., Oonk, H.B., Guerrero, F., De Loof, A., Janecka, A.E., Torfs, H., Vanden Broeck, J., 2005. Pharmacology of stomoxytachykinin receptor depends on second messenger system. Peptides 26, 109-114.

Pollock, N.J., Manelli, A.M., Hutchins, C.W., Steffey, M.E., MacKenzie, R.G., Frail, D.E., 1992. Serine mutations in transmembrane V of the dopamine D1 receptor affect ligand interactions and receptor activation. J. Biol. Chem. 267, 17780-17786.

Reale, V., Hannan, F., Hall, L.M., Evans, P.D., 1997a. Agonist-specific coupling of a cloned Drosophila melanogaster D1-like dopamine receptor to multiple second messenger pathways by synthetic agonists. J. Neurosci. 17, 6545-6553.

Reale, V., Hannan, F.L., Midgley, J.M., Evans, P.D., 1997b. The expression of a cloned Drosophila octopamine/tyramine receptor in Xenopus oocytes. Brain Res. 769, 309-320.

Robb, S., Cheek, T.R., Hannan, F.L., Hall, L.M., Midgley, J.M., Evans, P.D., 1994. Agonistspecific coupling of a cloned Drosophila octopamine/tyramine receptor to multiple second messenger systems. EMBO J. 13, 1325-1330.

Röser, C., Jordan, N., Balfanz, S., Baumann, A., Walz, B., Baumann, O., Blenau, W., 2012. Molecular and pharmacological characterization of serotonin 5-HT2 $\alpha$ and 5-HT7 receptors in the salivary glands of the blowfly Calliphora vicina. PLoS One 7. e49459.

Roth, B.L., Shoham, M., Choudhary, M.S., Khan, N., 1997. Identification of conserved aromatic residues essential for agonist binding and second messenger production at 5-hydroxytryptamine(2A) receptors. Mol. Pharmacol. 52, 259-266.

Sanyal, S., Wintle, R.F., Kindt, K.S., Nuttley, W.M., Arvan, R., Fitzmaurice, P., Bigras, E., Merz, D.C., Hebert, T.E., van der Kooy, D., Schafer, W.R., Culotti, J.G., Van Tol, H.H., 
2004. Dopamine modulates the plasticity of mechanosensory responses in Caenorhabditis elegans. EMBO J. 23, 473-482.

Spitzer, N., Edwards, D.H., Baro, D.J., 2007. Conservation of structure, signaling and pharmacology between two serotonin receptor subtypes from decapod crustaceans, Panulirus interruptus and Procambarus clarkii. J. Exp. Biol. 211, 92-105.

Srivastava, D.P., Yu, E.J., Kennedy, K., Chatwin, H., Reale, V., Hamon, M., Smith, T., Evans, P.D., 2005. Rapid, nongenomic responses to ecdysteroids and catecholamines mediated by a novel Drosophila G-protein-coupled receptor. J. Neurosci. 25, 6145-6155.

Strader, C.D., Dixon, R.A., Cheung, A.H., Candelore, M.R., Blake, A.D., Sigal, I.S., 1987. Mutations that uncouple the beta-adrenergic receptor from Gs and increase agonist affinity. J. Biol. Chem. 262, 16439-16443.

Strader, C.D., Sigal, I.S., Candelore, M.R., Rands, E., Hill, W.S., Dixon, R.A., 1988. Conserved aspartic acid residues 79 and 113 of the beta-adrenergic receptor have different roles in receptor function. J. Biol. Chem. 263, 10267-10271.

Strader, C.D., Candelore, M.R., Hill, W.S., Sigal, I.S., Dixon, R.A., 1989. Identification of two serine residues involved in agonist activation of the beta-adrenergic receptor. J. Biol. Chem. 264, 13572-13578.

Strange, P.G., 2005. Oligomers of D2 dopamine receptors: evidence from ligand binding. J. Mol. Neurosci. 26, 155-160.

Sugamori, K.S., Demchyshyn, L.L., McConkey, F., Forte, M.A., Niznik, H.B., 1995. A primordial dopamine D1-like adenylyl cyclase-linked receptor from Drosophila melanogaster displaying poor affinity for benzazepines. FEBS Lett. 362, 131-138.

Suo, S., Sasagawa, N., Ishiura, S., 2003. Cloning and characterization of a Caenorhabditis elegans D2-like dopamine receptor. J. Neurochem. 86, 869-878.

Swarz, F., Aebi, M., 2011. Mechanisms and principles of N-linked protein glycosylation. Curr. Opin. Cell. Biol. 21, 576-582.

Thamm, M., Balfanz, S., Scheiner, R., Baumann, A., Blenau, W., 2010. Characterization of the 5-HT1A receptor of the honeybee (Apis mellifera) and involvement of serotonin in phototactic behavior. Cell. Mol. Life Sci. 67, 2467-2479.

Thamm, M., Rolke, D., Jordan, N., Balfanz, S., Schiffer, C., Baumann, A., Blenau, W., 2013. Function and distribution of 5-HT2 receptors in the honeybee (Apis mellifera). PLoS One 8, e82407.

Torfs, H., Detheux, M., Oonk, H.B., Akerman, K.E., Poels, J., Van Loy, T., De Loof, A., Vassart, G., Parmentier, M., Vanden Broeck, J., 2002. Analysis of C-terminally substituted tachykinin-like peptide agonists by means of aequorin-based luminescent assays for human and insect neurokinin receptors. Biochem. Pharmacol. 63, 1675-1682.
Troppmann, B., Balfanz, S., Baumann, A., Blenau, W., 2010. Inverse agonist and neutral antagonist actions of synthetic compounds at an insect 5-HT1 receptor. Br. J. Pharmacol. 159, 1450-1462.

Troppmann, B., Balfanz, S., Krach, C., Baumann, A., Blenau, W., 2014. Characterization of an invertebrate-type dopamine receptor of the American cockroach, Periplaneta americana. Int. J. Mol. Sci. 15, 629-653.

Tsu, R.C., Wong, Y.H., 1996. Gi-mediated stimulation of type II adenylyl cyclase is augmented by Gq-coupled receptor activation and phorbol ester treatment. J. Neurosci. 16, 1317-1323.

Vandesompele, J., De Preter, K., Pattyn, F., Poppe, B., Van Roy, N., De Paepe, A. Speleman, F., 2002. Accurate normalization of real-time quantitative RT-PCR data by geometric averaging of multiple internal control genes. Genome Biol. 3. RESEARCH0034.

Verlinden, H., Vleugels, R., Marchal, E., Badisco, L., Pfluger, H.J., Blenau, W., Vanden Broeck, J., 2010. The role of octopamine in locusts and other arthropods. J. Insect Physiol. 56, 854-867.

Verlinden, H., Vleugels, R., Zels, S., Dillen, S., Lenaerts, C., Crabbé, K., Spit, J., Vanden Broeck, J., 2014. Receptors for neuronal or endocrine signalling molecules as potential targets for the control of insect pests. Adv. Insect Physiol. 46, 167-303.

Vleugels, R., Lenaerts, C., Baumann, A., Vanden Broeck, J., Verlinden, H., 2013. Pharmacological characterization of a 5-HT1-type serotonin receptor in the red flour beetle, Tribolium castaneum. PLOS ONE 8, e65052.

Vleugels, R., Lenaerts, C., Vanden Broeck, J., Verlinden, H., 2014. Signalling properties and pharmacology of a 5-HT7-type serotonin receptor from Tribolium castaneum. Insect Mol. Biol. 23, 230-243.

Vuerinckx, K., Verlinden, H., Lindemans, M., Vanden Broeck, J., Huybrechts, R., 2011. Characterization of an allatotropin-like receptor in the red flour beetle, Tribolium castaneum. Insect Biochem. Mol. Biol. 41, 815-822.

Wiemerslage, L., Schultz, B.J., Ganguly, A., Lee, D., 2013. Selective degeneration of dopaminergic neurons by MPP $(+)$ and its rescue by D2 autoreceptors in Drosophila primary culture. J. Neurochem. 126, 529-540.

Woodgett, J.R., Gould, K.L., Hunter, T., 1986. Use of synthetic peptides corresponding to physiological sites as probes for substrate recognition requirements. Eur. J. Biochem. 17, 177-184.

Wu, J., Xiao, H., Sun, H., Zou, L., Zhu, L.Q., 2012. Role of dopamine receptors in ADHD: a systematic meta-analysis. Mol. Neurobiol. 45, 605-620.

Yan, Z., Song, W.J., Surmeier, J., 1997. D2 dopamine receptors reduce N-type $\mathrm{Ca}^{2+}$ currents in rat neostriatal cholinergic interneurons through a membranedelimited, protein-kinase-C-insensitive pathway. J. Neurophysiol. 77, 1003-1015. 